\title{
SRM Awards
}

\section{Presented at the Society's 57th Annual Meeting in Salt Lake City, Utah on January 28, 2004. Presenting the awards is SRM President Bob Budd.}

\section{Frederic G. Renner Award}

The Frederic G. Renner Award is the highest bestowed by the Society for Range Management. The award is named for one of SRM's founding fathers and second president.

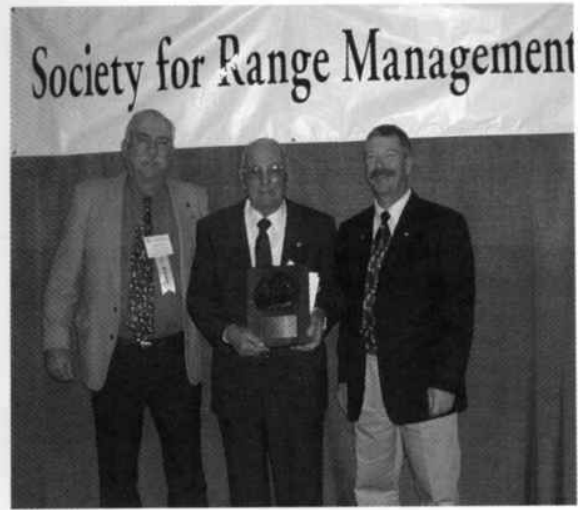

Hugh Thompson, Bill Hurst and President Bob Budd

William (Bill) Hurst is truly an amazing individual. At age 87 , a Charter Member and past president, Bill is still an active and involved SRM member. $\mathrm{He}$ is respected by all who know him. A true giant of the range management profession. The first annual ASRM meeting was held here in Salt Lake. Bill Hurst was here.This is also the state in which he was born and reared.

As a charter member of the Society, Bill's contributions to the art and science of range management have spanned more than six decades. Bill was born the son of an old-time Utah forest ranger and is the grandson of an original Gifford Pinchot era ranger and forest supervisor. He worked continuously for the USDA Forest Service from 1937 until 1976 except for two years of military service during World War II. Bill retired as regional forester of the Southwestern Region of the Forest Service.

After over a century of social unrest, the Spanish-American community of Northern New Mexico erupted into open revolt against the Forest Service in the mid 1960's. Bill Hurst guided the Forest Service through this sensitive situation and commissioned the "Northern New Mexico Policy" which resulted in the vast improvement in range conditions and administrative policy when implemented. In 2000, then regional forester Ellie Townsend commissioned Bill to do a follow-up review of the progress to date regarding implementation of that policy. In 2001 Bill presented his findings to the Southwestern Region forest officers. He is still the leading authority on forest and range management in the national forests in Northern New Mexico.

A primary criterion for the Renner Award is "sustained outstanding accomplishment(s) in, or contributions to any aspect of range science and range management by a member of SRM during the past 10 years. The word "sustained" is totally inadequate to describe Bill's staying power in contributing to both the Society and implementing practical and ethical land management on the ground. At 87, Bill is still going strong, attending and actively participating in annual as well as section meetings, and currently assisting the Denver office by keeping track and in contact with SRM's charter members.

Bill's 2000 publication, A Life Recalled, Memoirs of William Daly Hurst, almost epic at more than 800 pages, is a priceless documentation of over 80 years of history and events surrounding not only significant range management issues and policies, but in a greater sense, is an invaluable text on the philosophy, values and ethics by which all future generations of land managers should be guided.

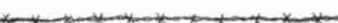

\section{W.R. Chapline Research Award}

The W.R. Chapline Research Award was established in 1986 to provide recognition to members of SRM for exceptional research accomplishments in range science and related disciplines.

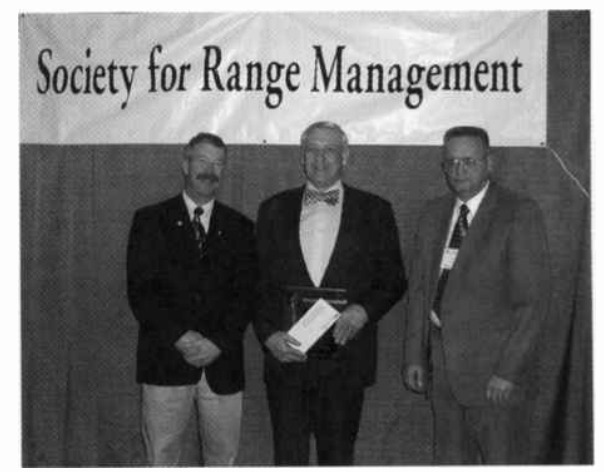

Bob Budd, Clenton Owensby and Walter Fick

Dr. Clenton Owensby's outstanding accomplishments span almost 40 years. His contributions have not been limited to any one focus area, but include notable accomplishments in the following areas: prescribed burning research including effects on production, botanical composition, carbohydrate reserves, brush \& weed control, soil properties \& steer diet and performance. Today he is internationally known for his work with tall-grass prairie response to elevated $\mathrm{CO} 2$ levels. $\mathrm{He}$ is currently quantifying the impact of grazing \& fire on carbon, water, and energy balance. This is critical to understanding the role of grasslands in carbon sequestration.

Dr. Owensby has contributed to the range management literature for over 35 years. This impressive contribution includes 93 refereed journal articles, 38 research bulletins, 11 extension leaflets, and 15 books and book chapters.

In addition to being an outstanding range scientist, Dr. Owensby is also an excellent teacher. $\mathrm{He}$ is responsible for teaching the introductory course in Range Management, Field Identification of Range and Pasture plants, Range Grasses, and Range Management Problems, at 
Kansas State University. His video offering of Range Management continues to be used by students throughout the U.S.

Dr. Clenton Owensby has without doubt made exceptional and sustained contributions to range management research.

\section{W.R. Chapline Stewardship Award}

The W.R. Chapline Stewardship Award was created in 1986 to provide recognition to members of SRM for exceptional accomplishments and contributions to the art and science of range management through specific rangeland entities.

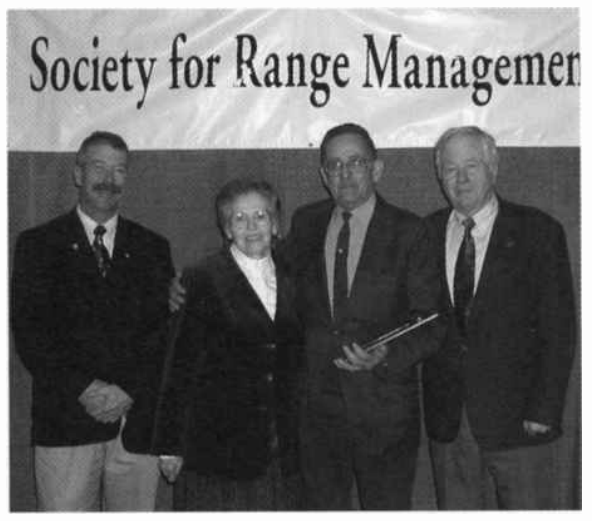

Bob Budd, Dorothy and Norman R. McClure and Kendall Johnson

Mr. Norman R. McClure has spent all his adult life striving for and achieving excellence in rangeland management - a span of $40+$ years! His ranch is a showcase of his accomplishments. He started with a tract of land and animals leased from his parents in north-central Washington. Norm has since built a thriving livestock operation composed of 180 commercial cows and operates on private, national forest, and Indian reservation lands. This operation is run primarily keeping the "vital 3-R's" in mind. These refer to Readiness, Rotation, and Residue! His phrase of: "The grass hurts before the cow hurts" was profiled in an earlier Western Beef profile of his operation.

Still, Mr. McClure's achievements are not measured solely by their effects on the land. They are measured as well in the strength of relationship between Norm and Dorthy McClure. Her contributions have not only helped achieve ranching success but have also added support for Norm's volunteer activities, often at some expense to personal and family time. Many of these additional activities involve an almost continual role in the Okanogan Conservation District, Washington Association of Conservation Districts, National Association of Conservation Districts, Washington Rangeland Committee

An extensive background in social ethics underlies a strong sense of social responsibility for natural resources. $\mathrm{He}$ is today a champion of an improved human condition as affected by proper use and management of natural resources and thus may have achieved perhaps the ultimate goal of good land stewardship - programs that make not only land but people bloom in time and place.

Norman's McClure is at once an exceptional landowner, manager, administrator, and counselor in the field of range management and supporting disciplines. So it is that he combines passion for the land with passion for people-surely the mark of an accomplished land steward.

\section{Outstanding Achievement Award}

The Outstanding Achievement Award is presented to the individuals or groups for eminently noteworthy contributions in advancing the science and art of range management.

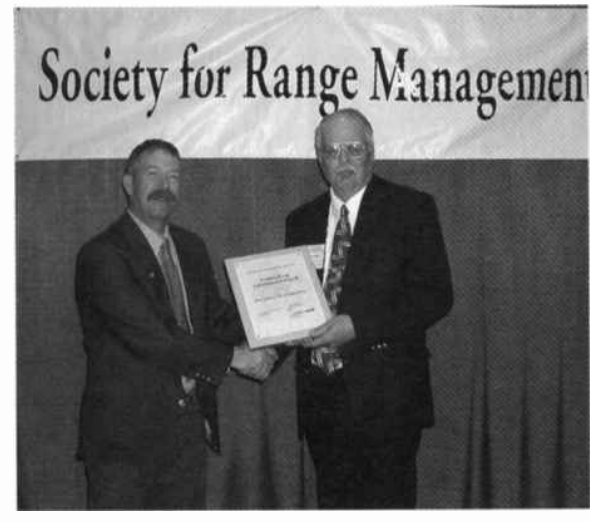

Bob Budd and Dean Anderson

Dr. Dean M. Anderson has made outstanding contributions to rangeland management through highly creative, sometimes imaginative; scientific endeavors to develop technologies that can improve the application of grazing management of rangelands. He has devoted himself to the careful, thorough and exacting pursuit of identifying the basic tenets of grazing animal behavior and management. His research has spanned predator protection, animal distribution, and forage management.

Dr. Anderson conceived a method, now patented, to manage free-ranging animals in real time with virtual boundaries using radio frequency signals from navigational satellites. He conceived a novel approach to reduce coyote predation in range sheep flocks by bonding ewes with cattle. $\mathrm{He}$ is also pioneering a new flourometry technique to rapidly characterize the botanical contents of the diets of livestock and wild ruminants in real time.

Dr. Anderson served on a select panel to the National Academy of Sciences to evaluate agricultural research in Pakistan. He has also presented numerous technical papers at the New Mexico Section, the Society, and the International Rangeland Congresses in Denver, Australia, India, and South Africa, and has served the Society on several committees.

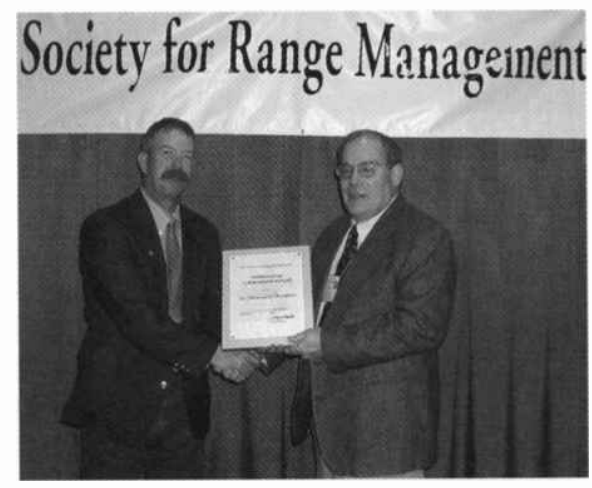

Bob Budd and Thomas Boutton

Dr. Thomas W. Boutton is internationally recognized in the development and application of stable isotope methodologies in soil science, ecology, agronomy and biogeochemistry of the grassland and savanna ecosystems of North America and Africa. His high quality, timely and relevant studies have been widely published in a number of highly respected scientific publications. His recent work on controls over soil respiration and decomposition processes have put him at the forefront of key issues of carbon sequestration on rangelands.

One of Dr. Broutton's key contributions has been the development and application of isotopic techniques for detecting and quantifying changes in plant cover that have occurred in response to environmental variation and human land uses. He has provided a powerful tool to study the dy- 
namics of natural and managed ecosystems and to facilitate a better understanding of the evolution of grasslands following the end of the last glacial period.

Dr. Boutton's invaluable contributions on nutrient and water cycles and energy flow has facilitated a better understanding of the principles of conservation and sustainable use of rangeland ecosystems by land managers around the world.

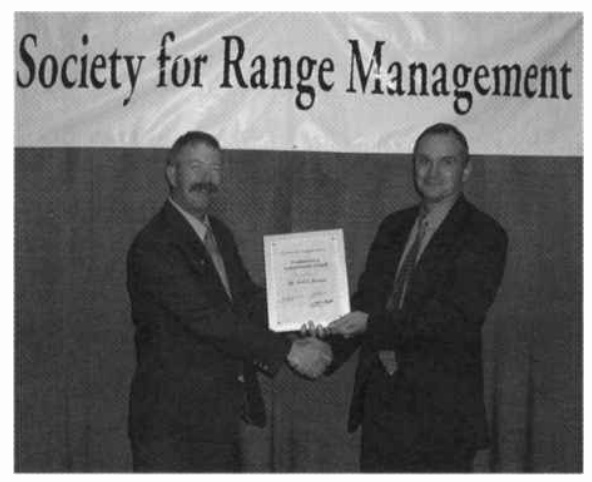

Bob Budd and Joel Brown

Dr. Joel R. Brown has made outstanding contributions to the field of rangeland management as a practicing conservationist, scientist, and policy advisor. Dr. Brown began his involvement with the Society as an undergraduate on the Ft. Hays State University plant team, and has served on numerous committees, as a paper presenter and chaired symposia and technical sessions.

He has been instrumental in providing intellectual leadership in developing new ecological theories relevant for practical application of rangeland management. His studies of basic ecological systems, vegetation dynamics and state-and-transition concepts involve breaking new ground considering non-linear, non-equilibrial approaches to vegetation change. His research works in Australia, the study of the key processes of shrub invasion of grasslands, and his leadership to develop new ecological theories into practical management applications central to proper range management. He has also provided technical guidance to develop reasonable and realistic expectations for evaluating and managing national programs related to greenhouse gases and soil carbon sequestration to NRCS and USDA in his role as Special Assistant to (NRCS) Chief for Global Change.

Dr. Brown has devoted his career to critical analysis of the basic tenets of our profession in an effort to "get them right."

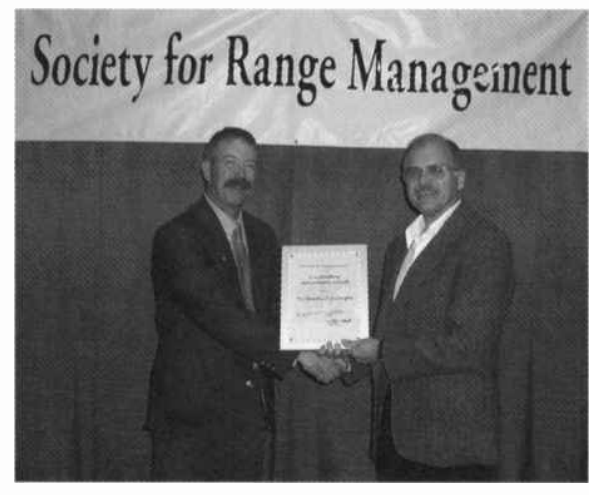

Bob Budd and Timothy Fulbright

Dr. Timothy E. Fulbright is recognized for his work in applying range science methods and approaches to understanding and improving wildlife habitat. His range improvements and habitat manipulation research has ranged from: breaking dormancy and transplanting important woody species for white-winged dove habitat; methods to successfully restore vegetation on the Coastal Sand Plain; improving the summer nutritional status of white-tailed deer; and shrub community reestablishment and succession pathways following rootplowing. His work on warm season forages is especially noted for the identifictions of lablab, a subtropical legume, as a forage that would survive the hot, dry summers while remaining highly palatable - this changed the planting of food plots for deer from a practice held in disdain to one now commonly used throughout the southeastern United States.

International recognition has come from his work in northern Mexico, Bulgaria and the Middle East. He is the only range scientist currenly on the International Arid Lands Consortium Research and Development Advisory Committee. He has also been active on many committees at the Society level. On the Texas Section level, he has chaired numerous committees, served on the Board of Directors and served as President. He encourages Section members to strengthen ties with related organizations and groups, seek ways to improve public knowledge and perception of range science, and to recognize the increasing importance of recreation on rangelands.

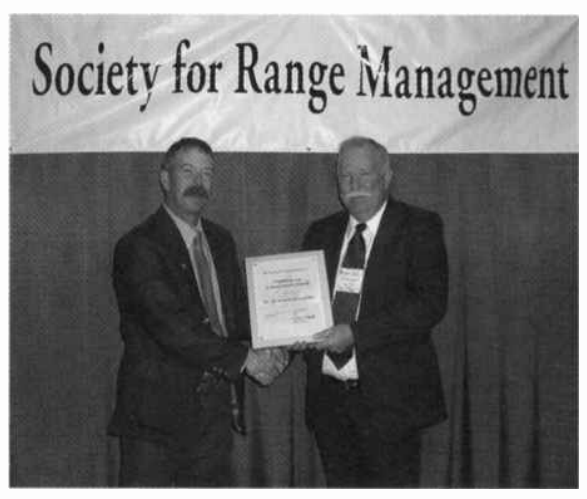

Bob Budd and C. Wayne Hanselka

Dr. C. Wayne Hanselka is a leader in comprehensive integrated rangeland management educational programs within the Texas A\&M Extension Program. Effective technology transfer is a cornerstone of achieving proper rangeland management and his innovation and vision to develop comprehensive, integrated educational programs that meet the needs of a diverse landowner base, while insuring the productivity and sustainability of the rangeland resources.

Dr. Hanselka has demonstrated exceptional talent and ability to build multi-disciplinary partnerships across students, landowner groups, disciplines, societies, agencies, states and even countries. These successful broad-based partnerships range from teams involving the use of native plants and ecological processes to repair the dynamic cycles on rangeland, to Spanish goats in South Texas, to Project Range Care - all of which serve as models for partnership building. His work with Spanish goats has been instrumental to a significant increase in the number of herds as well as the formation of two American Meat Goat Associations.

Dr. Hanselka does not limit his efforts to Texas. He has extended educational efforts to Mexico, and has close relationships with universities and cattlemen below the border. $\mathrm{He}$ is also active within the Texas Section and the Society, serving on numerous committees in $20+$ years - a few of which are: the International Affairs Committee, chaired the Advisory Council, was co-chair of the 1988 Annual Meeting in Corpus Christi and served as a liaison between SRM and Mexico for the 1990 summer meeting in Monterrey. 


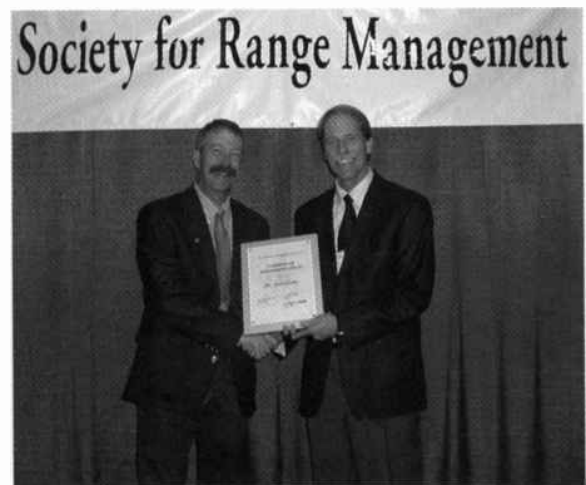

Bob Budd and Don Kirby

Dr. Donald R. Kirby is passionate about proper management of our natural resources. He provides land managers of North Dakota and the Northern Plains with sound, cost-effective solutions from mine reclamation to invasive weed management to the impacts of grazing mismanagement. Regardless of the political implications of a subject, one can be assured that Dr. Kirby's recommendations will also be based upon the research and his best professional judgment - without personal bias.

Dr. Kirby, at the invitations of the Governor of North Dakota and the US Forest Service, has served on the 1999 and 2002 Scientific Review Panels of the Forest Service Dakota Grassland Plan. He is also passionate about the North Dakota Youth Camp, the NDSU Range Club, Undergraduate/Graduate student paper events, and URME Coach. He is a member of several professional socieites, he is widely published with over 130 publications, and has received numerous honors and awards.

Dr. Kirby is also very dedicated to the Society. His positive "can-do" attitude, commitment to rangeland science, has had him involved with many Section and Society committees. He has served as Section President, and recently served on the Society's Board of Directors.

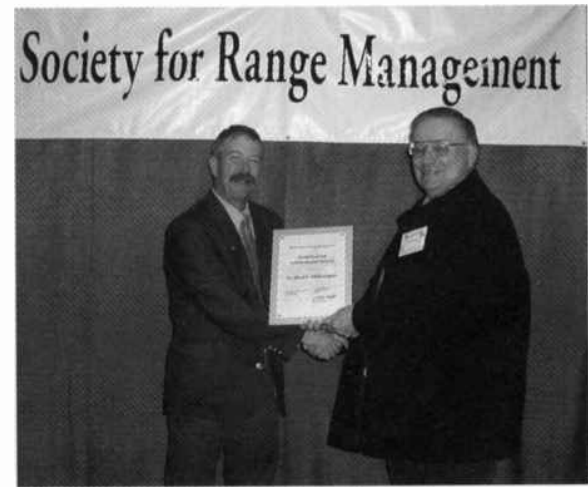

Bob Budd and Paul Ohlenbusch

Dr. Paul E. Ohlenbusch is a strong advocate for the use and proper management in sustaining grazing lands across Kansas and the Great Plains. Although an Extension specialist, he has conducted an applied research program on haying and grazing of CRP stands, brush and weed control, prescribed burning, revegetation of disturbed sites, cool-season grass stands and development of procedures and materials to guide producers in determining options for water quality from grazinglands all of which has been extensively published. He is further recognized for developing and conducting in-depth schools and workshops.

An active member of the Society since his undergraduate days, he was one of the early users of computers for presentations and technology transfer, as evidenced by the number of websites he has developed and maintained. Dr. Ohlenbusch is a sought after presenter to a variety of media outlets and he has adapted his extension program to meet the changing needs of the clientele.

A consistent contributor to SRM, Dr. Ohlenbusch has been active in serving on, or chairing, many Section and Society Committees and has helped host three annual meetings.

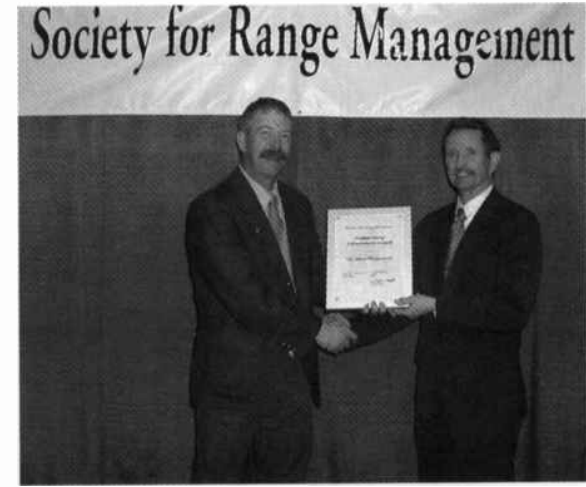

Bob Budd and Steven Whisenant

Dr. Steven G. Whisenant is considered one of the most influential restoration ecologists in the world for his work on disturbed and degraded rangelands and forests. His book, Repairing Wildlands: a process-oriented, landscape-scale approach, is the most widely used ecological restoration book in the world. This book was the first publication to propose and develop a strategy for process-oriented, landscape-scale approach to restoring damaged lands and sustaining them over time with minimal inputs and costs, which is rapidly becoming the standard for ecological restoration.

Dr. Whisenant is internationally acclaimed for work on projects in China, Niger, Poland, Kuwait, Syria, Saudia Arabia, Iran, Jordan, Taiwan, and Afghanistan. His ideas on ecological restoration make him a sought after presenter at conferences in Australia, Costa Rica, and China, to name a few of the recent meetings. He is regulary asked to participate in or lead research projects or other activities in forests, wetlands, and even urban areas.

Prior to his arrival at Texas A\&M University, Dr. Whisenant taught at Brigham Young University in Provo, Utah. He is a leader in teaching methodology as one of his current classes is internet-only, with students in several states. Dr. Whisenant has also served on several Section and Society committees.

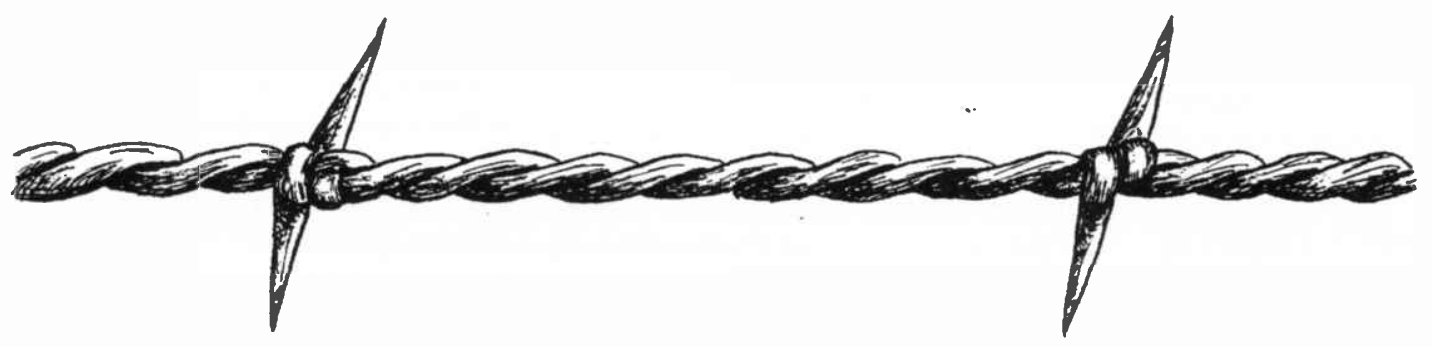




\section{Fellow Award}

The title of Fellow is conferred upon members of the Society for Range Management in recognition of the exceptonal service to the Society and its programs in advancing the science and art of range-related resource management. This high honor is granted in the belief that special recogniton should be given for exceptional and dedicated service to the Society.

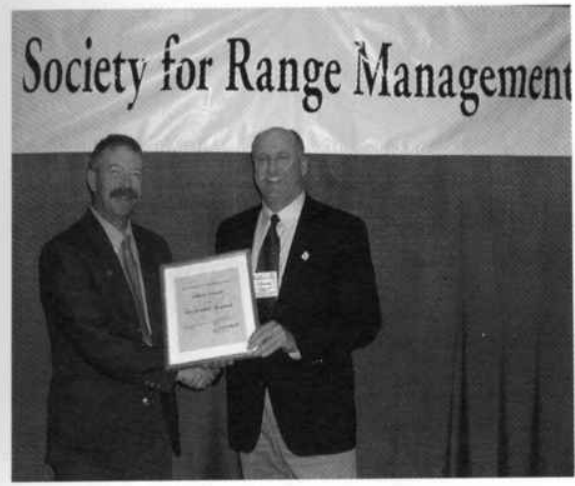

Bob Budd and Fred C. Bryant

Dr. Fred C. Bryant has provided exceptional service to the Society for Range Management and the profession of range management since 1974. Few people have been as dedicated to the advancement of the Society and even fewer have been as effective. He served continuously in a leadership role from 1977 through 1996. He did an outstanding job as president of the Texas Section in 1991 and of the Society in 1995. During this time, he has served on numerous committees.

He has not only provided leadership in the profession but made major contributions in range and wildlife ruminant research. In the process of research, teaching and international projects he has made major contributions in grazing management. He has directed a ruminant project in Peru (10 years), Bolivia (5 years), and Morocco (2 years).

Dr. Bryant was recognized as an outstanding teacher and university administrator by Texas Tech University when he received the institutions' Academic Achievement Award in 1989 and the Outstanding Alumnus Award in 1999. In addition to other awards, many of his students have gone on to take active leadership, research and education roles in the profession.

During Dr. Bryant's career, he has published 50 refereed publications in scientific journals, 75 technical papers, published one book and 3 book chapters. His research findings on ruminant nutrition, grazing management and livestock/wildlife relationships are used worldwide. He has truly served the Society with distinction.

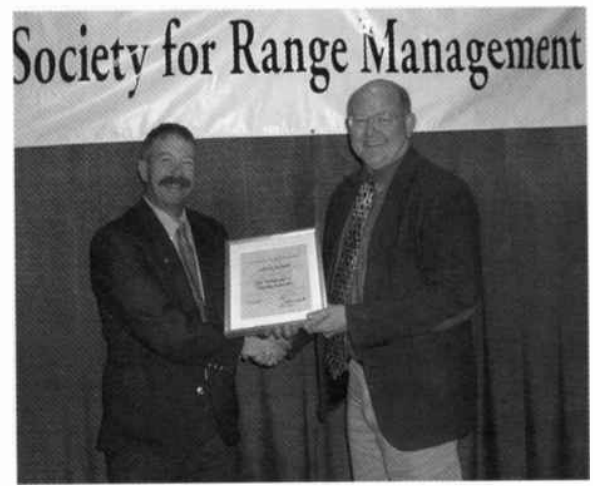

Bob Budd and Rodney K. Heitschmidt

Dr. Rodney Heitschmidt has been a stalwart in the Society during his 37 years of membership. At the Section level, he has served on several committees. He has not only worked diligently for the society, he has been exceptionally effective. To his credit, he consistently strives to work across disciplines to foster understanding of how the different components of rangeland ecology and management interact. He also applies an intellectual curiosity to understand the perspectives of the different users of rangeland resources. These traits have contributed to Dr. Heitschmidt's effectiveness both as a scientist and leader.

During Dr. Heitschmidt's 30+-year research career, he has authored or co-authored over 200 articles and 85 abstracts. As a grassland ecologist, he has focused his research largely on understanding livestock grazing processes both from an ecological and production agriculture perspective. Many of his successes are measured by the:

- large number of special invitations received to speak at a broad array of local, regional, national and international meetings \& conferences

- reprint requests from scientists around the world (current count is now from 30 countries

- the many times his work is cited in other state-of-the-art publications

And lastly, his election as Director, $2^{\text {nd }}$ Vice President, and President of the Society for Range Management is most certainly a measure of the esteem in which his professional colleagues hold Dr. Heitschmidt.

Dr. Heitschmidt's leadership and vision have resulted in very significant tangible impacts in terms of influencing scientific insight which then was translated into policy and practice. His important contributions to range management programs both in terms of research and human resource development have been exemplary.

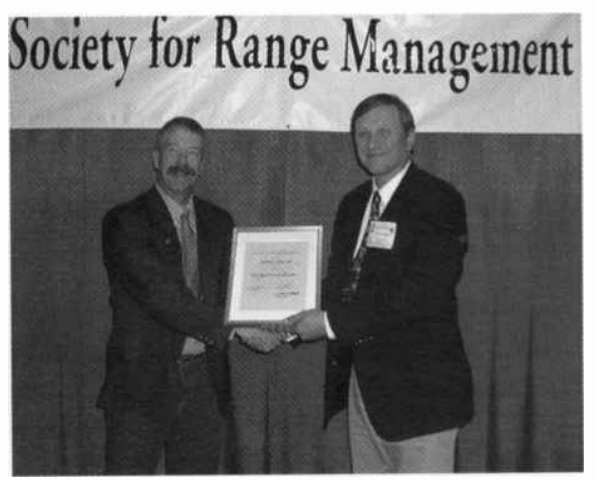

Bob Budd and Barron S. Rector

Dr. Baron Rector's service to SRM for the past 29 years is enthusiastic, infectious, and certainly long lasting! Hundreds of youth have learned valuable range management information, leadership and public speaking skills due to the efforts of Dr. Rector. And, he shows no signs of slowing down!

The Range Management profession does not have a more enthusiastic promoter than Baron Rector. As an Extension Range Specialist his duties include an array of activities across the state of Texas. He educates people through demonstration projects such as seeding projects, determining range plant quality and production, grazing management, woody plant growth and forage quality. Recent years have seen him addressing urban audiences on the topic of urban sprawl and its effects on rangelands. Additionally, he is called upon by outside agencies and groups for guidance on these urban issues.

Perhaps Dr. Rector's most effective contribution to the profession of Range Management is that of enlightening youth about this field. He has a gifted ability to inspire these folks to learn! People marvel at his infectious enthusiasm and seemingly boundless energy to lead these folks. Largely through the efforts of Dr. Rector, the Texas Section Youth Range Workshop has succeeded for nearly 50 years and is recognized as the longest running activity of this kind in the nation.

Dr. Rector's important contributions to range management programs in terms of human resource development and educating our youth have been outstanding. 


\section{Sustained Lifetime Achievement Award}

This award is presented to SRM members for long-time contributions to the art and science of range management and to the Society for Range Management.

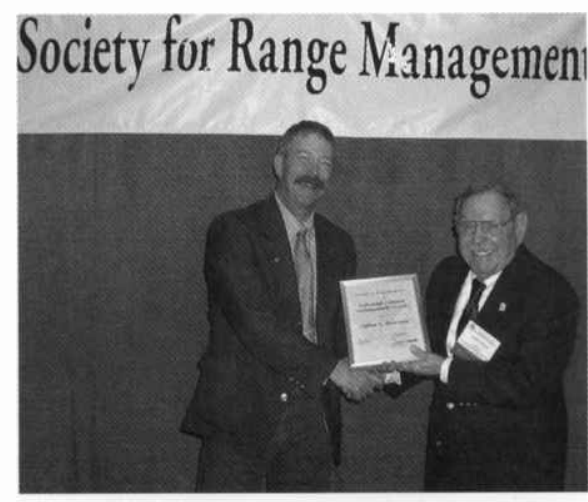

Bob Budd and James Brunner

James Brunner, Charter Member of the Society for Range Management and a member for 55 years. He has been active in several SRM sections, most notably, Nevada, Arizona, and the Pacific Northwest.

After receiving his BS Degree in Range Management in 1941, he trained to do range surveys in Idaho and Colorado with the Forest Service. He trained under Dr. Dyksterhuis with the SCS to learn range site classification and condition classes. He later worked with the BLM on land and mineral adjudication, land examinations, and Cadastral surveys. He also worked with BLM in Arizona at the state office in planning. When World War II broke out, he received training of another sort - as an officer in the US Army Signal Corps dealing with field artillery. He spent 6 years in the European Theatre.

This man is an inspiration! He is 85 years old and constantly puts much younger individuals to shame with his never failing energy, enthusiasm, willingness, and positive attitude. Until 2 years ago Mr. Brunner made annual trips to Nevada to monitor rangeland vegetation transects which he had established decades earlier. He believed in the work which was being done and took it upon himself to see it through even though he had been retired from the BLM for over a quarter century.

Mr. Brunner currently writes on environmental issues specializing on salmon, sagegrouse, and global warming. He writes for the Oregon Fish \& Wildlife Journal, Journal of Range Management, Rangelands, Outdoor Life, Sports Afield, and several newspapers. He is sometimes accused of being "politically incorrect" but never - "scientifically incorrect". He simply "tells it like it is".

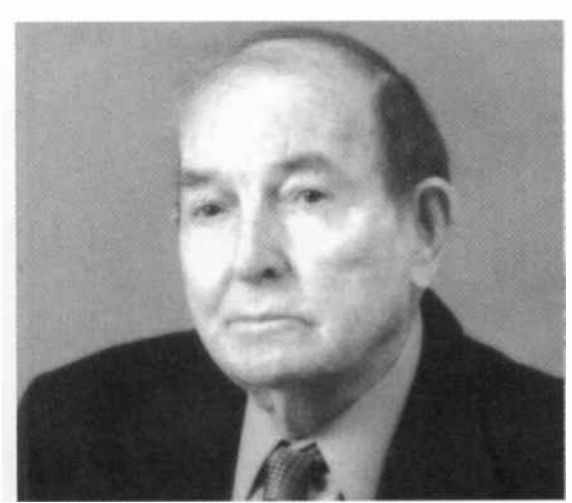

Marion Everhart

Marion Everhart, a Charter Member of the Society for Range Management and a member for 51 years. He has 62 years of federal service from 1938 to 2000 with three government agencies; NRCS (then SCS); USDI - Bureau of Reclamation; and USDJ-US Attorney in the Land and Natural Resources Division.

Marion has devoted his entire life to natural resources, land, and land economics. He was born on a small ranch in Kansas; graduated from Kansas State College with a degree in Botany. He was a U.S. Naval Officer in WW II. He began his career with the SCS in Texas as a Range Conservationist, later becoming an Area Range Specialist. A Charter Member of the Society, he served as President of the Texas Section in 1961.

After 15 years with SCS he transferred to the Bureau of Reclamation and was staff appraiser, Regional Supervisory Appraiser, with the Chief Appraisal Branch serving from Texas to California. $\mathrm{He}$ also became president of the National Association of Review Appraisers and on the advisory committee of the International College of Real Estate Consultants. He was even elected to "Who's Who in the West"!

$\mathrm{He}$ is the author of more than 75 technical and scientific publications, numerous articles and two books. Mr. Everhart has inventoried and/or appraised millions of acres of rural land in almost every state. In the Dept. of Justice he has prepared numerous appraisal reports and been used as an expert witness many times. He has been recognized nationally for such work.

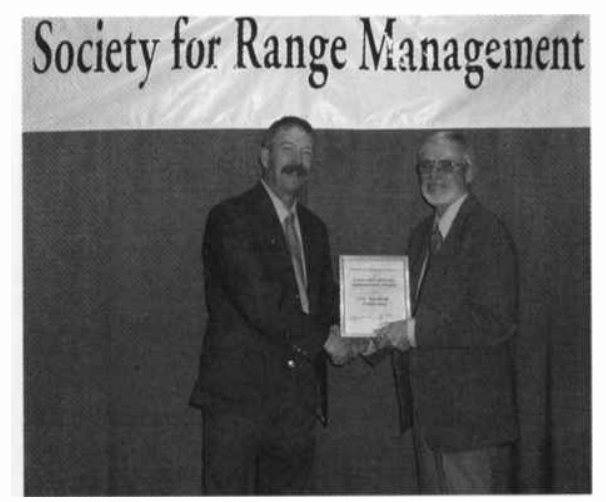

Bob Budd and Marshall Haferkamp

Dr. Marshall Haferkamp, has been involved in educational activities in the field of Range Management with his teaching career and three Universities, and continuing with his career with ARS.

Marshall has been an active member of SRM for 39 years, serving as committee member and officer in the Texas, and Northern Great Plains Sections. He has served on numerous committees at the parent Society level, chaired several, and is currently Associate Editor of the Journal of Range Management.

Through the ARS and Universities he has worked with peers, producers, agency personnel, and academia concerning information discovered by his research. This illustrious career spans almost 40 years of aggressive, state-of-the-art technical developments in range management. During this time, Marshal has contributed over 255 published documents and made more than 50 presentations in both technical and non-technical forums.

Dr. Haferkamp's areas of greatest contributions to research include:

- Germination traits of rangeland plants for seasonal pastures in restoration ecology and understanding of life history for problem spp. such as Japanese Brome.

- Developing effective planting, establishment and post-establishment grazing schemes for planted forages;

- Developing effective drought management strategies

- Developing management plans for: a) ameliorating adverse effects of Japanese Brome. Marshall probably knows more about the ecology and biology of this species than any other person in the world!

- Member of ARS investigating the role that US rangelands have in carbon sequestration. 


\section{Outstanding Young Range Professional Award}

This Outstanding Young Range Professional Award was inaugurated by SRM in 1988 to recognize the promise and potential of our younger members. One of the major criteria for this important award is the age of the nominees, who must have been less than 35 years old on January 1, 2004.

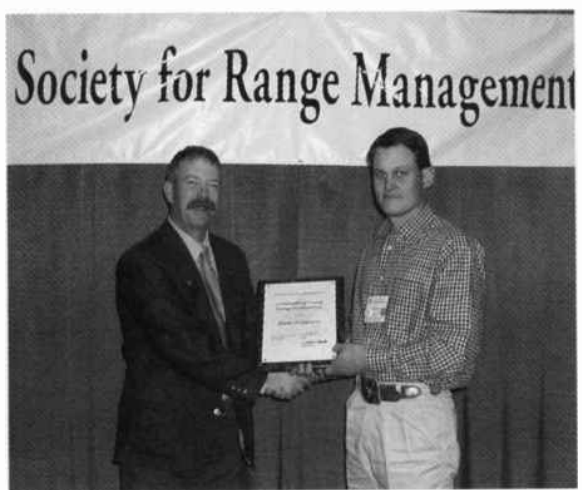

Bob Budd and Wade Anderson

Wade Anderson stands apart from the "crowd" when it comes to enthusiasm and passion for rangeland management. He has made a difference! He came to Oklahoma assigned to a field office that had gone stale on their range program. In a very short time, he generated his own cadre of clients and jumpstarted the program. His eagerness and enthusiasm was apparent by the requests he got for assistance. He's a willing volunteer to promote rangelands and to educate others about their importance for a variety of multiple uses and values.

Wade graduated at the top of his class at Texas Tech. When he graduated, Texas NRCS was not hiring. He was brave enough to move to California which took courage and also showed his dedication to the field of range management. It is remarkable that Wade now has experience in three states and is not yet 30 years old. He is now back in Texas however.

Wade Anderson's enthusiasm, and dedication serve as an outstanding example for the youth of today to follow in the management of our natural resources.

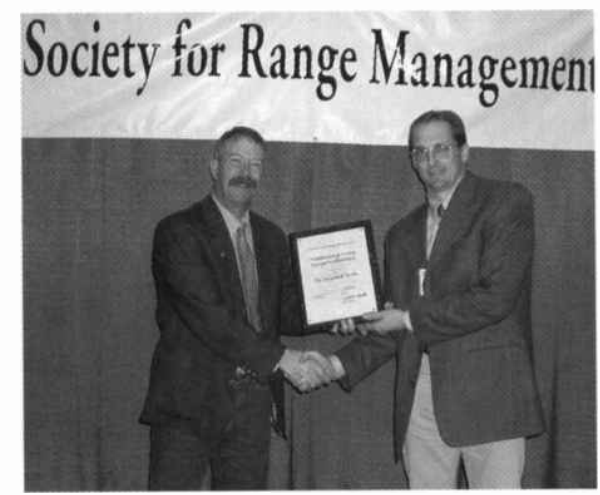

Bob Budd and Edward Bork

Dr. Edward Bork is highly motivated, with a deep and abiding love for rangelands and an obvious desire to manage and conserve them for future use. He's a willing volunteer at every opportunity to promote rangelands and to educate others about their importance for a variety of multiple uses and values. Ed has been involved in SRM since he began his undergraduate education at the University of Alberta. His contributions to his sections and the parent Society are already notable.

Despite his high level of activity in both the research and teaching areas, Dr. Bork has also maintained a particularly strong extension program, in part through the key collaborative partnerships he has established with numerous provincial and private industry extension specialists. Dr. Bork has been very active in conducting workshops and presenting the results of his research at various conferences, field days, and symposia.

Dr. Bork's enthusiasm, and dedication serve as an outstanding example for the youth of today to follow in the management of our natural resources.

\section{RSEC Undergraduate}

\section{Teacher Award}

The Outstanding Undergraduate Teaching Award is presented annually to the individual who makes the greatest contribution to undergraduate education in the broad discipline of range science. The award is presented jointly by the Range Science Education Council and the Society for Range Management.

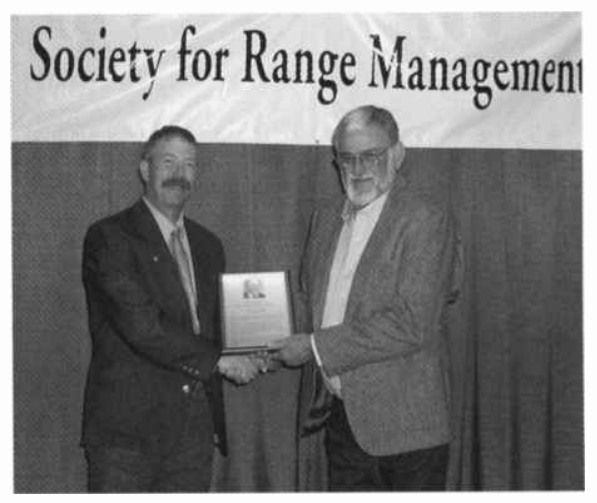

Bob Budd and Carlton Britton

The recipient of the Award in 2004 is Dr. Carlton M. Britton, Professor, Department of Range, Wildlife, and Fisheries Management, Texas Tech University.

Dr. Britton's formative years were spent on the Box Ranch near Caprock where his father was ranch manager. Carlton spent his teen years on the Mescalera Apache Indian Reservation near Ruidoso where his father was ranch manager for the Mescalera Apache Native American Tribe. He graduated from Capitan High School (Capitan, N.M.) and attended Texas Tech University where received the B.S. and M.S. Degrees in Range Management. Before continuing his education toward the Doctorate Degree, Carlton served as a technician and Fire Chief for the Prescribed Burning Program at Texas Tech University under the tutelage of Dr. Henry Wright. He subsequently attended Teas A\&M University where he received the Ph.D. Degree in Range Science under Dr. Jim Dodd.

Upon completion of the Ph.D. Degree, Dr. Britton was Assistant (1975-1980) and Associate (1980) Professor at Oregon State University, Burns, Ore. In 1980, Carlton returned to Texas Tech University to join the faculty in the Department of Range, Wildlife, and Fisheries Management. Carlton has served both the University and the range profession in many ways. One of his greatest contribu- 
tions to the profession has been in the area of writing professionally for both the lay reader and the scientific community. Carlton has served as Associate Editor for $J R M$, Editor for the JRM Handbook and Style Manual Revision, and Editor for the Texas Journal of Agriculture and Natural Resources. He is currently preparing a history of the Box Ranch on which he was reared. He served as Director of the Texas Tech Research Ranch and coordinator of research on the Ranch for 20 years.

In addition to Carlton's many responsibilities, his first love and one of his greatest contributions to the University and to the range profession is teaching. In recognition of his teaching prowess he has received the President's Excellence in Teaching Award, Texas Tech University (1999) and was inducted into the Teaching Academy, Texas Tech University (2000). Carlton has taught a number of courses within the Department. He is the one on whom the Department calls when someone is no longer able to teach their class for whatever reason. He is always very willing and is certainly capable of filling this role when he is called upon.

Although Carlton has taught several different courses, his specialties are Fire Ecology, Principles of Range Management (for non-majors), and Range Analysis and Management Planning. His expertise in prescribed burning makes him a natural to teach the Fire Ecology course. In addition to teaching Fire Ecology at Texas Tech University, he regularly teaches a fire shortcourse for ranchers and technicians. The experience that his students receive in his "fire" courses prepares them to be leaders in the use of prescribed fire as a management tool in natural resources. This is evidenced by the number of individuals throughout the West and Southwest that were trained by Dr. Britton directly or in consortium with Dr. Henry Wright.

Carlton's educational experiences have prepared him to teach Principles of Range Management, but his ranching heritage has prepared him to reach out to those individuals in other disciplines that ultimately will manage family or corporate properties. He brings a lifetime of experiences as well as a very solid educational career to the classroom to share with students across many disciplines outside of range science.

Above all of the aforementioned attributes of teaching, the greatest that he offers is in the capstone course of Range
Analysis and Management Planning. Students complete this course with a depth of understanding and a breadth of knowledge far beyond their expectations. In this course, Carlton teaches the importance of incorporating multiple components of resource issues into a ranching operation. Students are expected to create a ranch plan that not only encompasses management of the rangeland for livestock production, but also includes manipulation of the rangeland resources for wildlife habitat, recreation and nature tourism. It is the most thorough management plan that the students can expect from any course and prepares them for the kinds of plans that they will prepare throughout their careers. As one student wrote "I do not think I have ever been as proud of anything in my school career as I was when I handed in the final copy of my range plan. I am sure that Dr. Britton had many other projects going on at the time but when he was with us we were given his full and undivided attention and I do not think that any of us will ever forget it."

Some of the descriptors used by Dr. Britton's former students concerning him and his classes include the following: "good science", "good sense", "curious mind", "rapier sharp wit", "affable personality", "real-life experiences", "honesty", "strong character", "enthusiasm", "passion for communicating knowledge to students", and "it is obvious Dr. Britton loves his work."

The Excellance in Range Management Award has gone to XU BE ranch in Oklahoma.

\section{Outstanding Range Management Award}

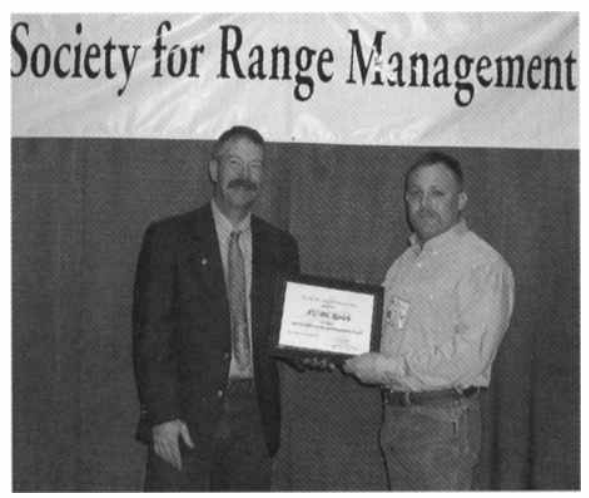

Bob Budd and Troy Daniel, Shelby Ranches

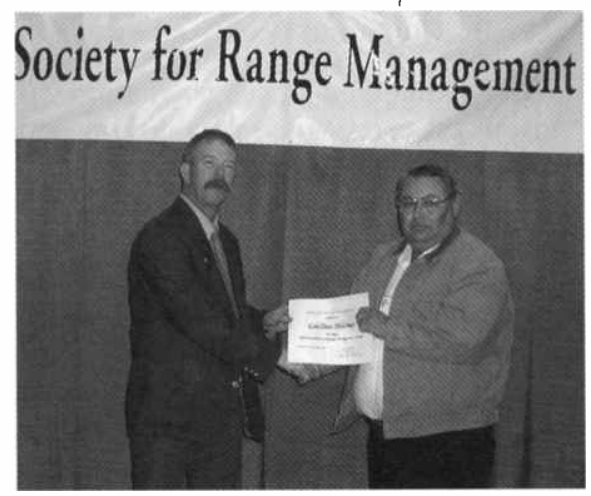

Bob Budd and Vivian Garcia

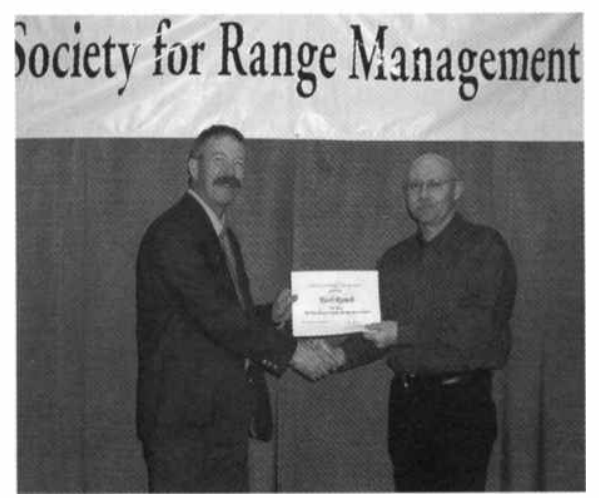

Bob Budd and Gene Waterson 


\section{Annual Meeting Winners High School Youth Forum Winners}

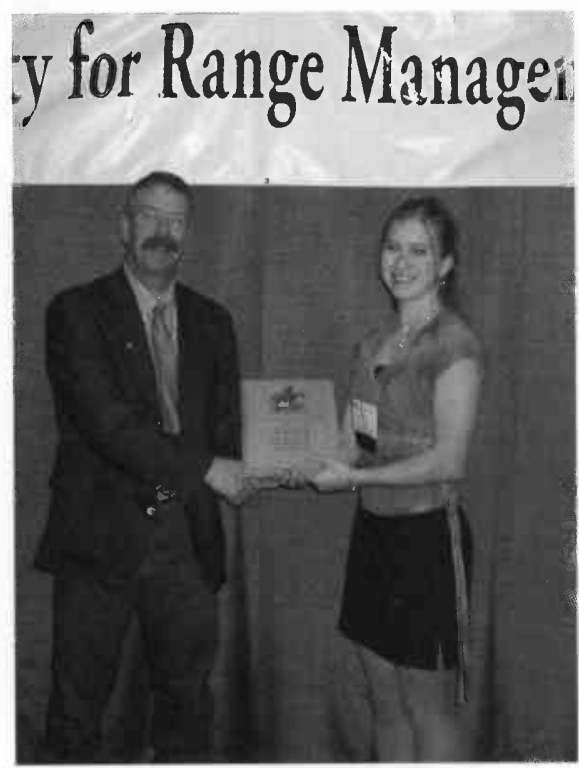

1st Place: Shelly Taylor (Nebraska Section) and President Bob Budd.

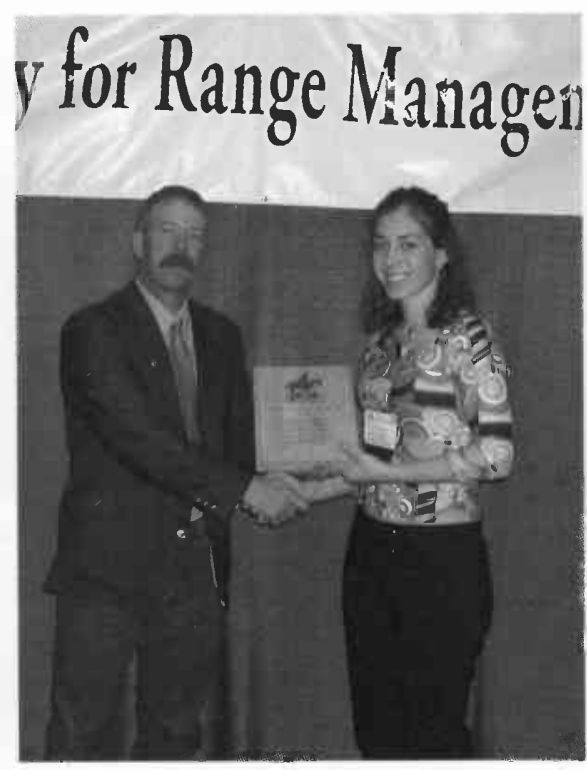

2nd Place: Emily Kuecker (South Dakota Section) and President Bob Budd.

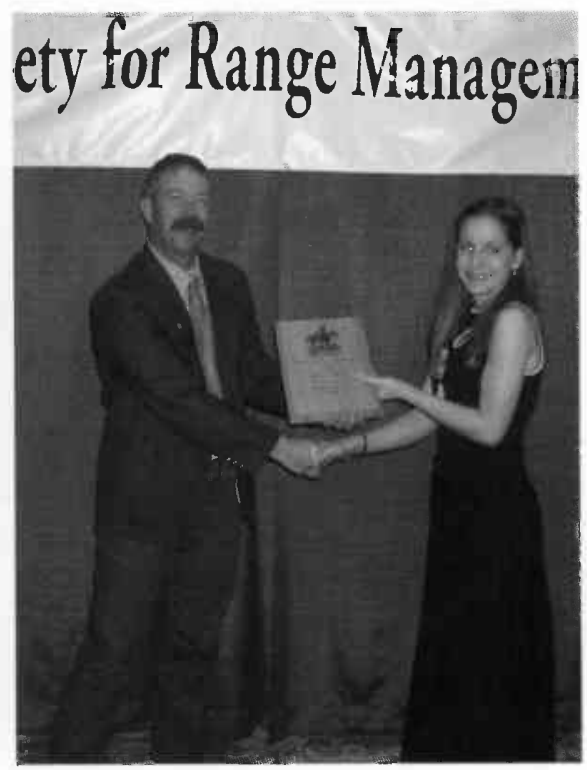

3rd Place: Allison Pyssen (Texas Section) and President Bob Budd.

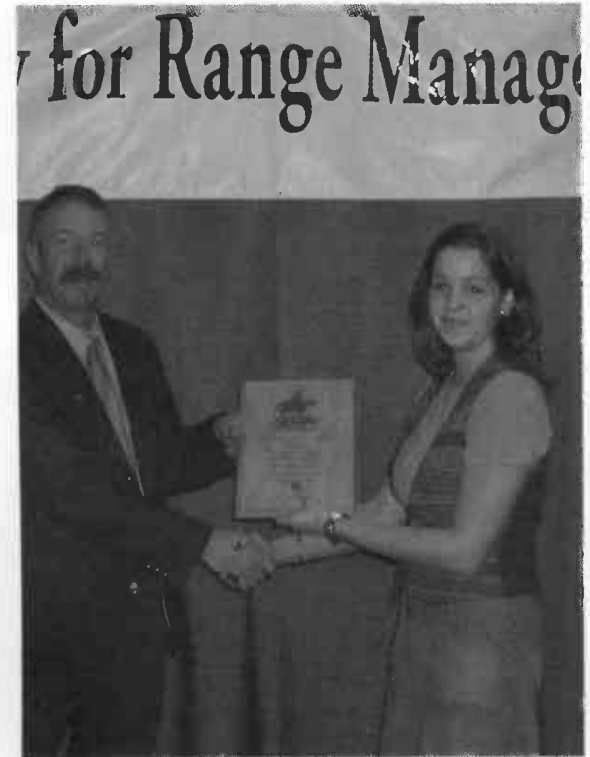

4th Place: Samantha Moehr Northern Great Plains Section) and President Bob Budd.

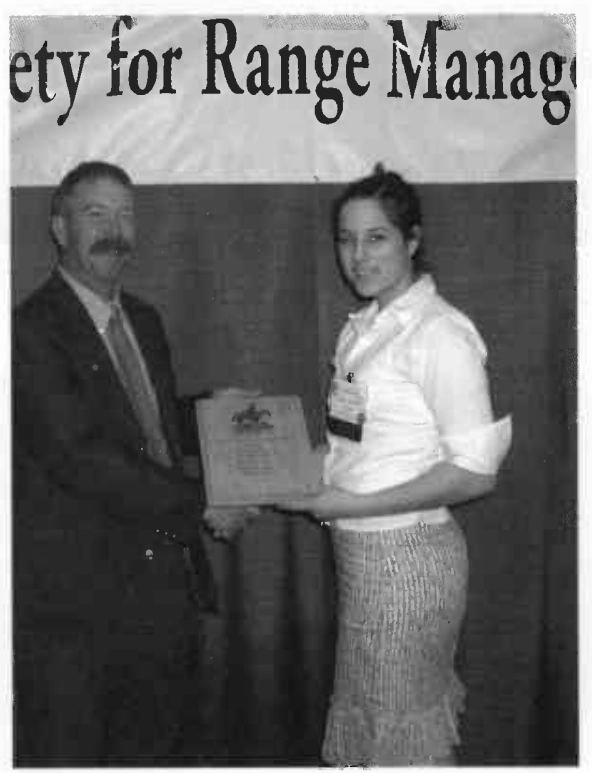

5th Place: Amanda Abughosh (California Section) and President Bob Budd. 


\section{Undergraduate Range Management Exam Winners}

Team

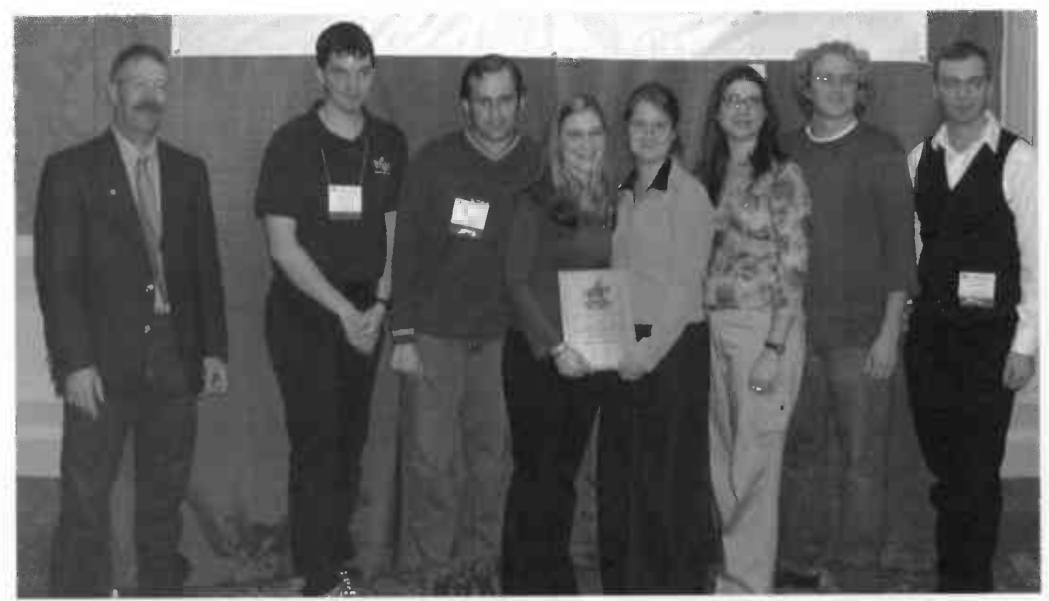

1st Place: (University of Alberta), (Alphabetically) Kurtis Fouquette, Danielle Gabruck (3rd Place Individual), Marilyn Germaine, Kali Hicks, Cameron Klause, Cody Nahirniak (2nd Place Individual), Steven Tannas, and President Bob Budd.

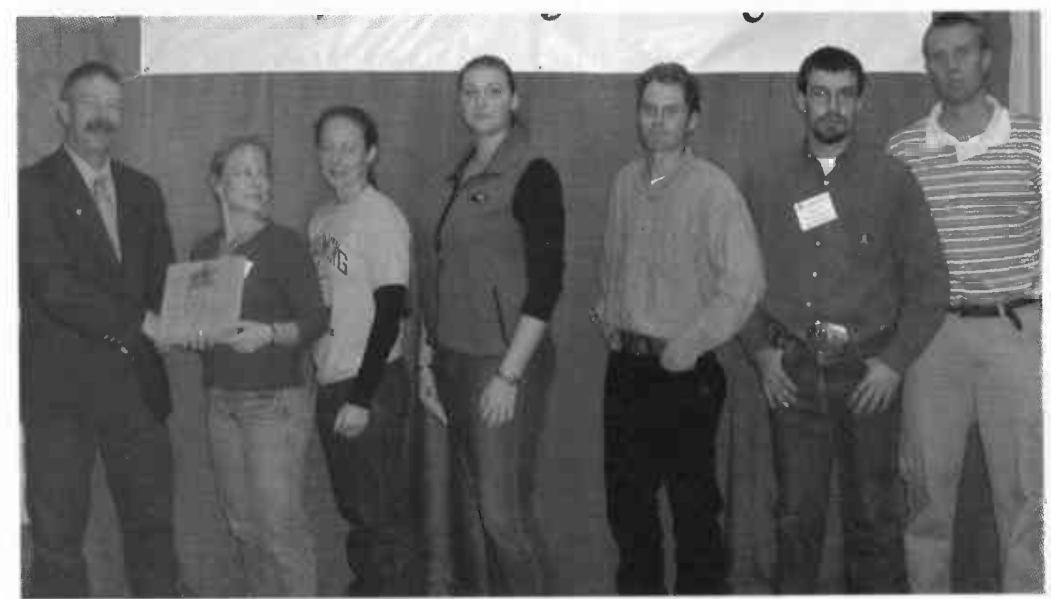

2nd Place: (University of Wyoming), (Alphabetically) Kyle Hagerty, Jocelyn Johnson, Jordge LaFantasie (1st Place Individual), Matthew Scott, Teven Thomas, Aaron Zobell and President Bob Budd.

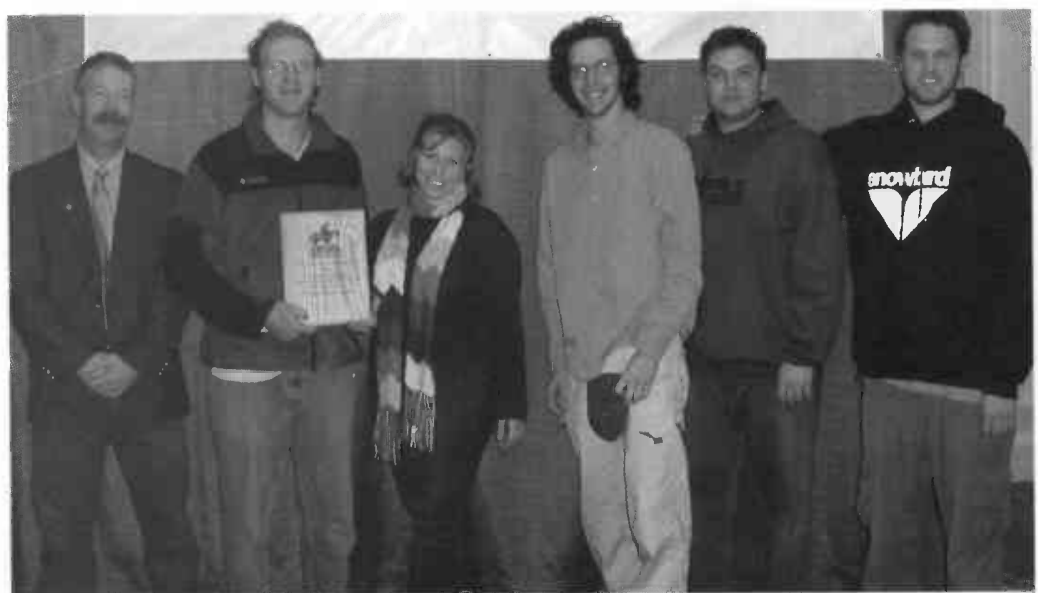

3rd Place: (Colorado State), (Alphabetically) Bryan Criswell, Jesse Dillon, Peter Landon, Seth Ratering (5th Place Individual), Elissa Yoder, and President Bob Budd.

\section{Individual}

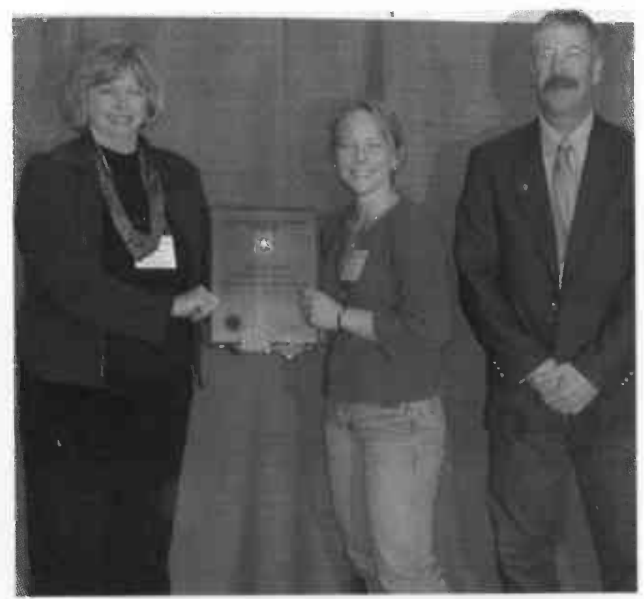

1st Place USFA Award: Janette Kaiser, Jordana (Jordge) Lafantasie (University of Wyoming) and President Bob Budd.

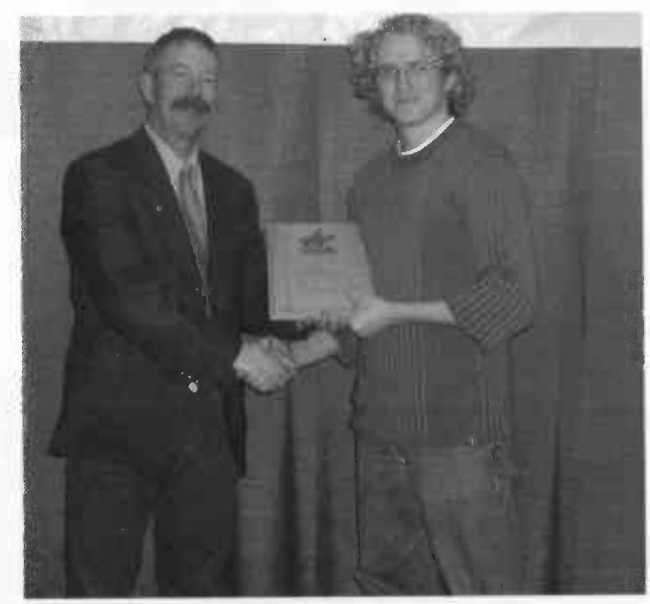

2nd Place Award: Cody Nahirniak (University of Alberta) and President Bob Budd.

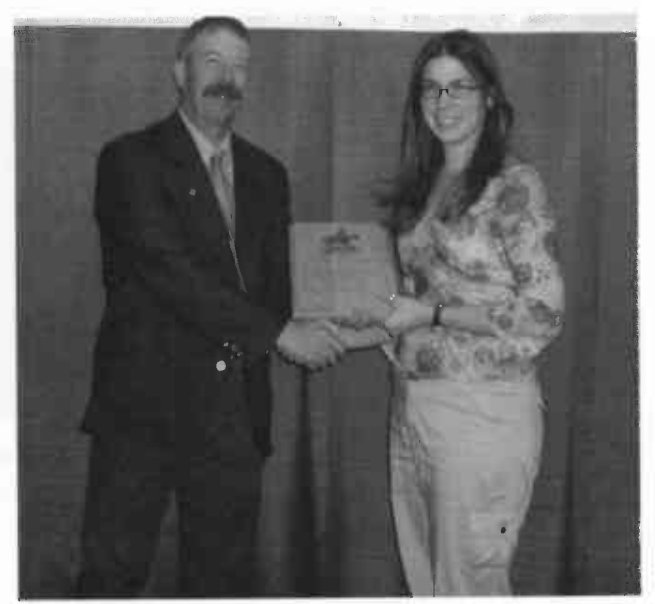

3rd Place Award: Danielle Gabruck (University of Alberta) and President Bob Budd. 


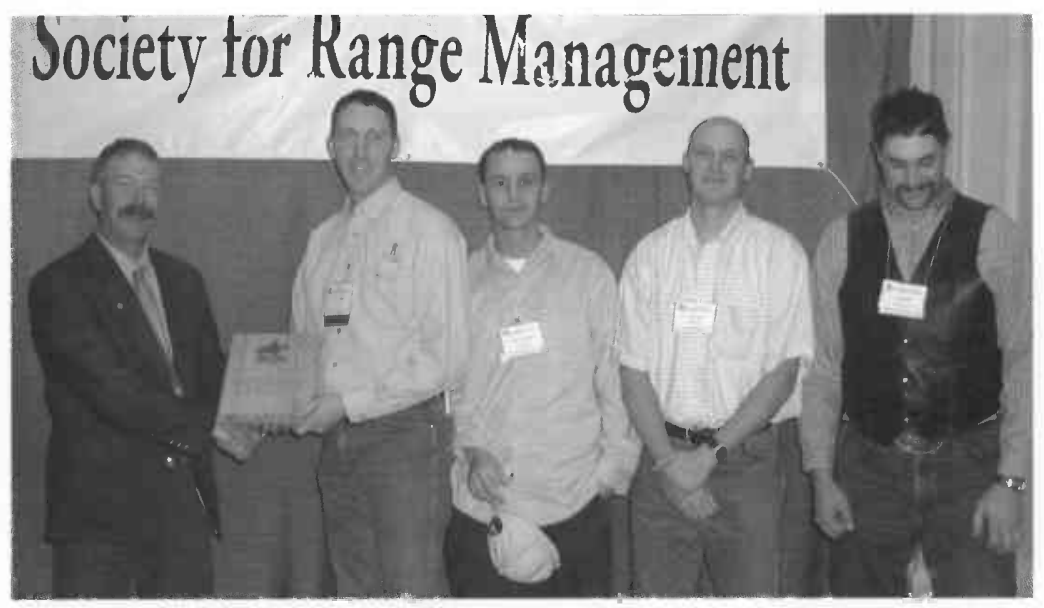

4th Place: (Utah State), (Alphabetically) Garry Brown, Boyd Hatch, Morgan Mendenhall, Travis Mote, and President Bob Budd.

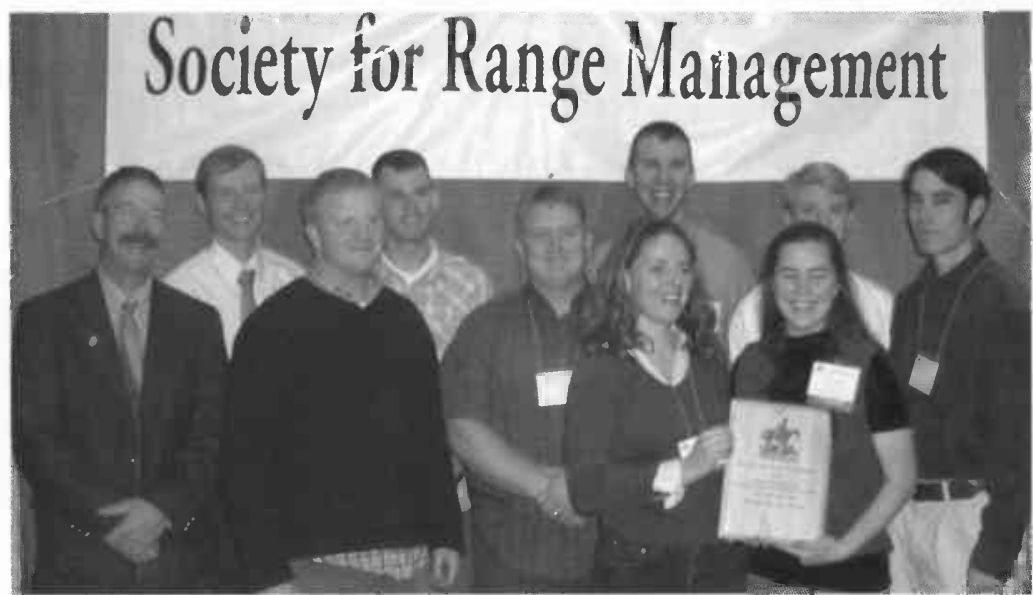

5th Place: (Brigham Young University), (Alphabetically) Jeremiah Armstrong, Eric Gardner (4th Place Individual), Ryan Huish, Thomas Krebs, Luke Marchant, Leland Roberts, Matt Stevenson, Ruth Walker, Tina Ward, and President Bob Budd.

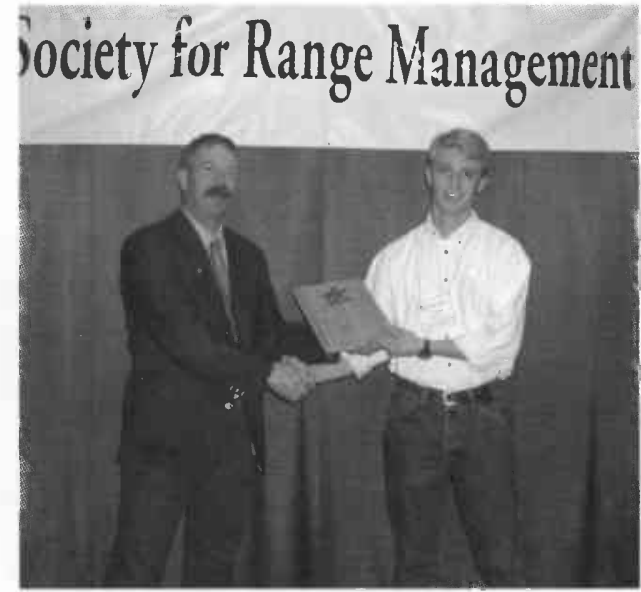

4th Place: Eric Gardner (Brigham Young University) and President Bob Budd.

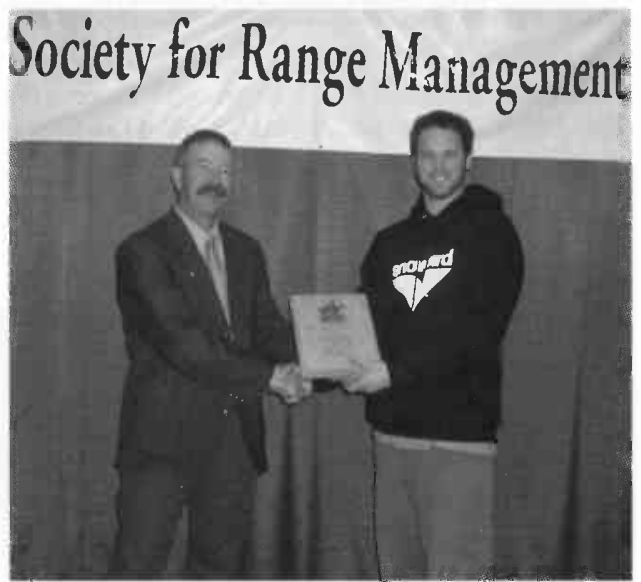

5th Place: Seth Ratering (Colorado State University) and President Bob Budd.

\section{Undergraduate Public Speaking Contest Winners}

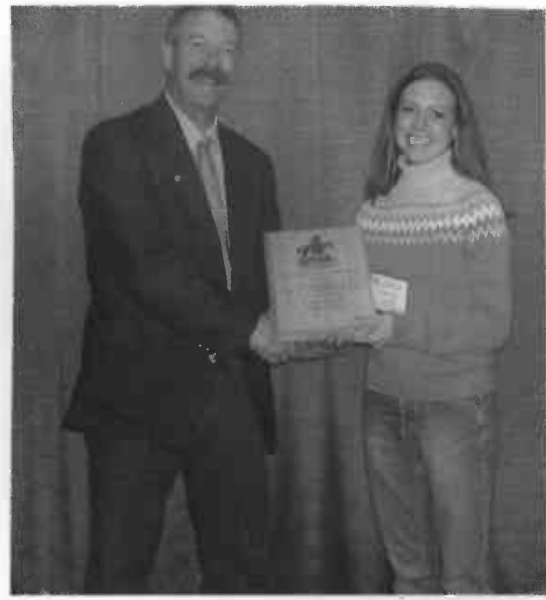

1st Place: Rachel Shorma (University of Wyoming) and President Bob Budd.

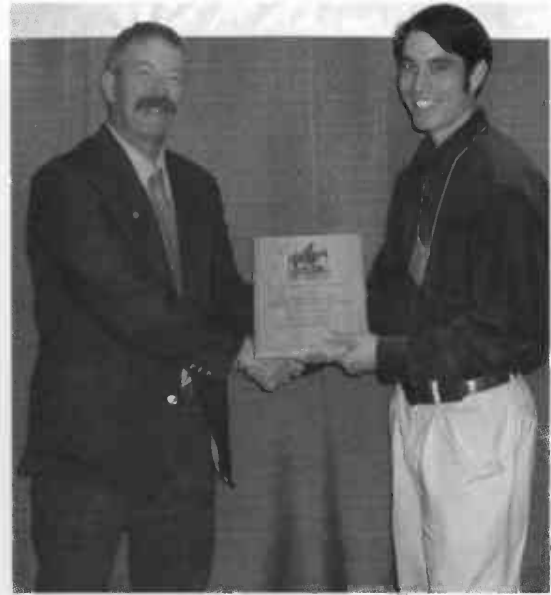

2nd Place: Matt Stevenson (Brigham Young University) and President Bob Budd.

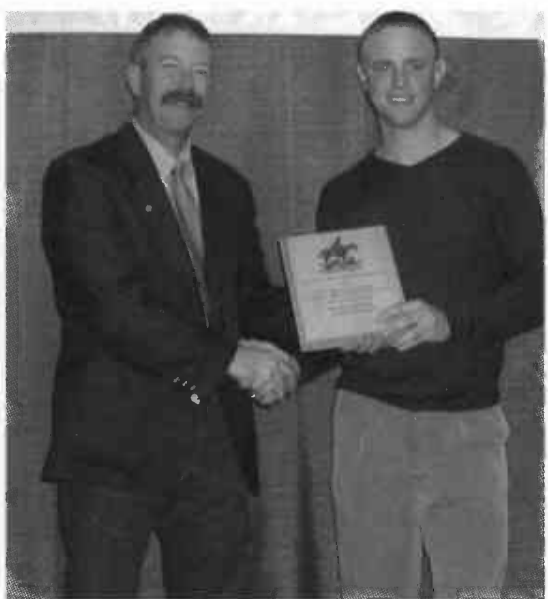

3rd Place: Jeffrey Thigpen (Texas A\&M University) and President Bob Budd. 


\section{Range Plant Identification Winners}

\section{Team}

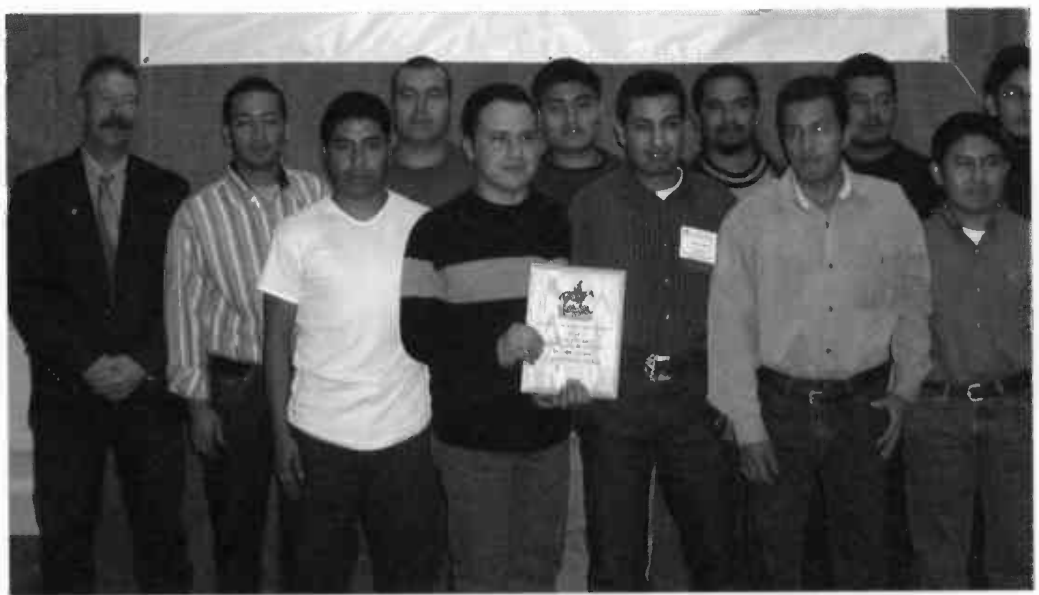

1st Place: (Antonio Narro), (Alphabetically) Pascual Gallegos Ayala (5th Place Indvidual), Eduardo Ponce Castro (4th Place individual), Abid Francisco Moo Cruz (1st Place BLM winner), Miguel Angel Grageda Garcia, Felipe Loyo Melchor, Damian Gaytan Quiroz (2nd Place individual), Jose L. Guerrero Soto, Raul Jimenee Tirado, Victor Victoria Utriilla, Edgar G. De Anda Villarreal (3rd Place individual), Ignacio Velasco Vite, and President Bob Budd.

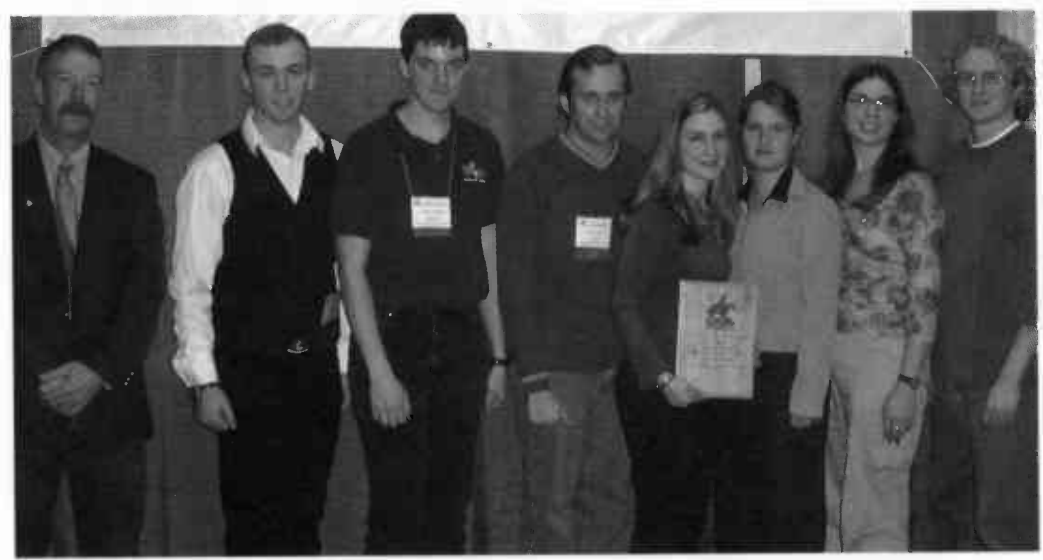

2nd Place: (University of Alberta), (Alphabetically) Kurtis Fouquette, Danielle Gabruck, Marilyn Germaine, Kali Hicks, Cameron Klause, Cody Nahirniak, Steven Tannas, and President Bob Budd.

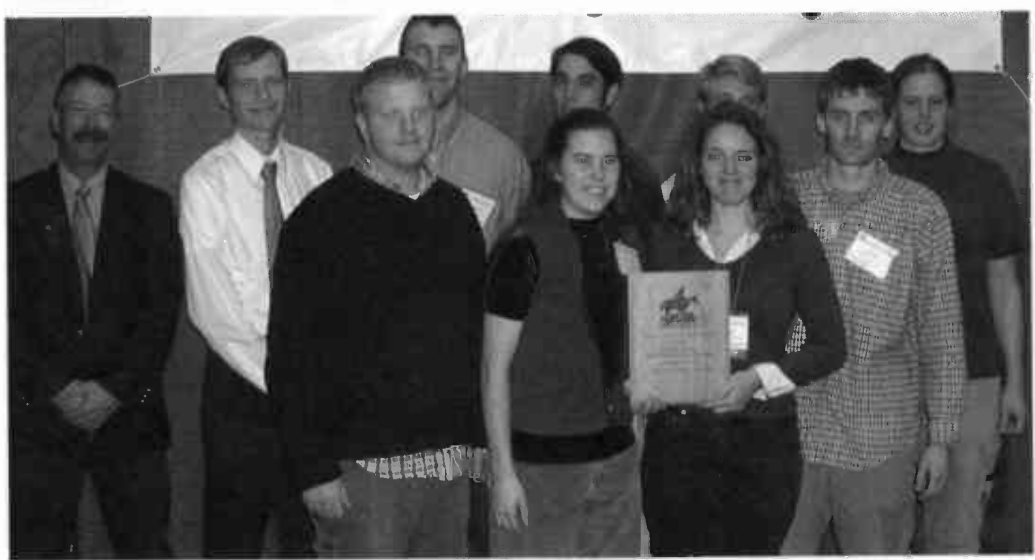

3rd Place: (Brigham Young University), (Alphabetically) Neal Bryan, Rachel Fugal, Eric Gardner, Ryan Huish, Thomas Krebs, Luke Marchant, Matt Stevenson, Tina Ward, Ruth Walker, and President Bob Budd.

\section{Individual}

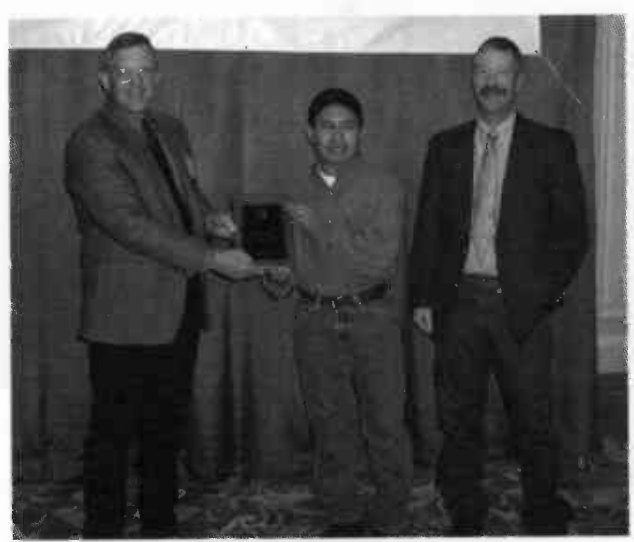

1st Place BLM Award: Bob Bolton, Abid Francisco Moo Cruz (Antonio Narro) and President Bob Budd.

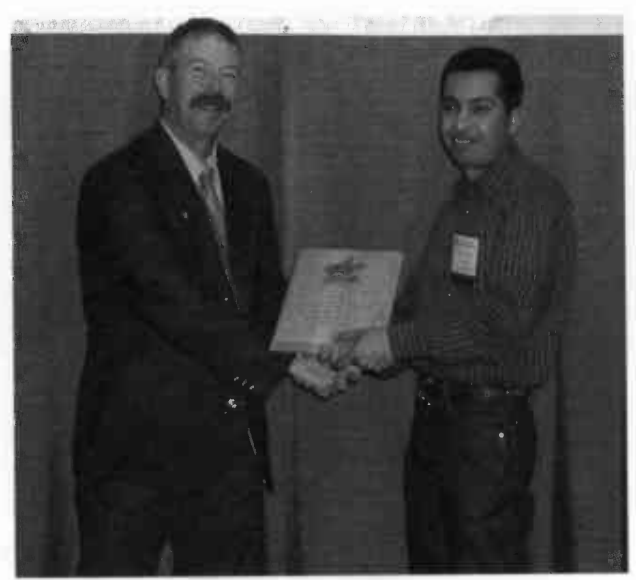

2nd Place Award: Damian Gaytan Quiroz (Antonio Narro) and President Bob Budd.

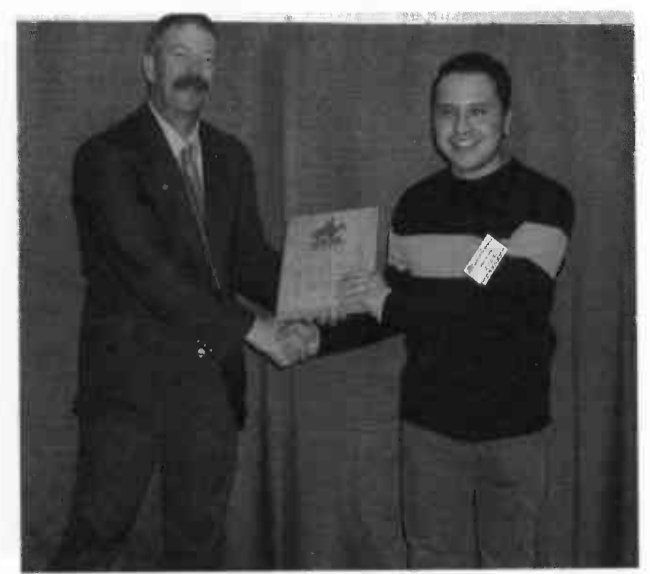

3rd Place Award: Edgar G. De Anda Villarreal (Antonio Narro) and President Bob Budd. 


\section{Team}

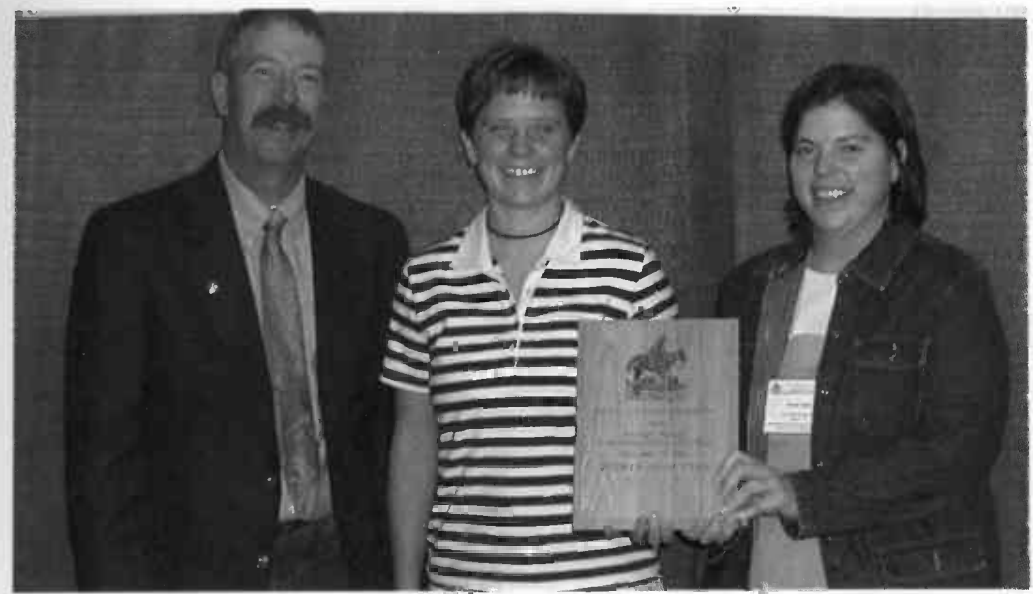

4th Place: (Utah State Valley College), (Alphabetically) Allyson Bench, Wendy Yates and President Bob Budd. (Not shown) Chris Bolzodi, Brad Johnson, Joshua Simpson, and Mike Wujua.

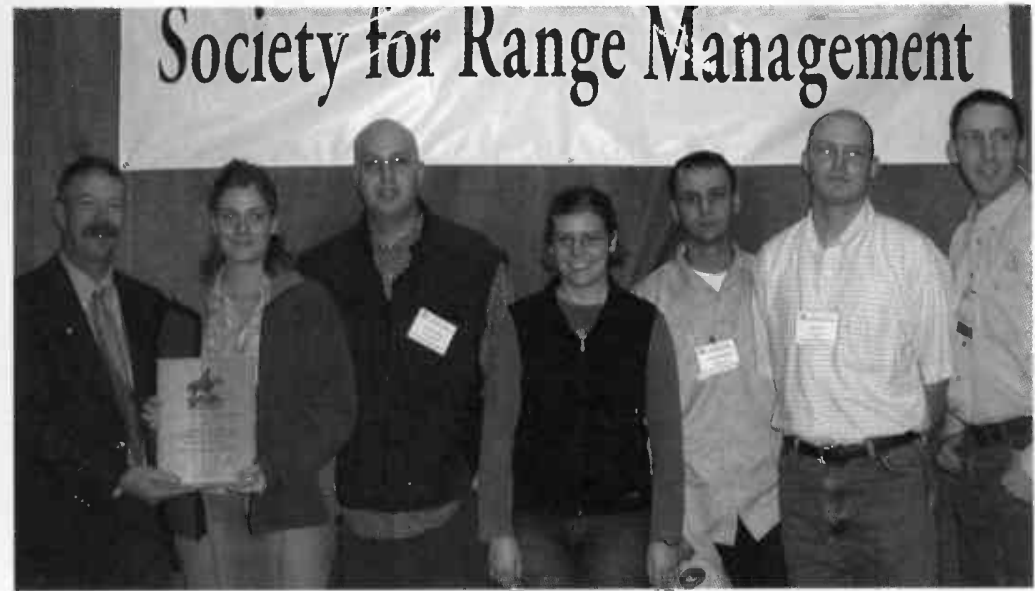

5th Place: (Utah State University), (Alphabetically) Garry Brown, Aimee Zobell Harrison, Boyd Hatch, Morgan Mendenhall, Sarah Quistberg, Damon Winter, and President Bob Budd.

\section{Individual}

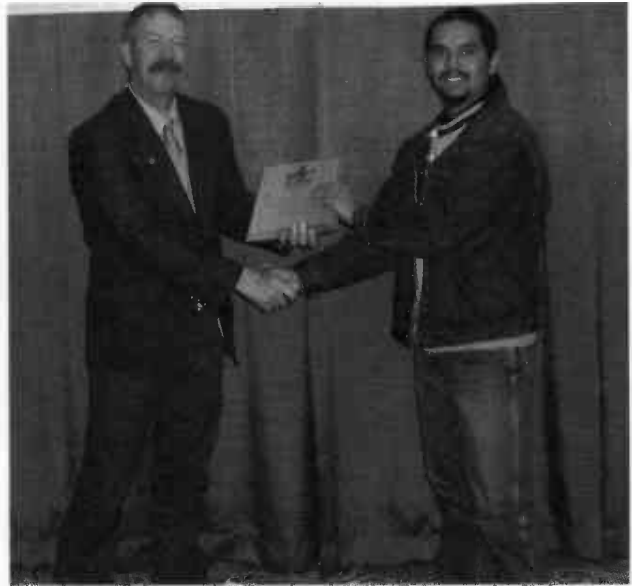

4th Place: Eduardo Ponce Castro (Antonio Narro) and President Bob Budd.

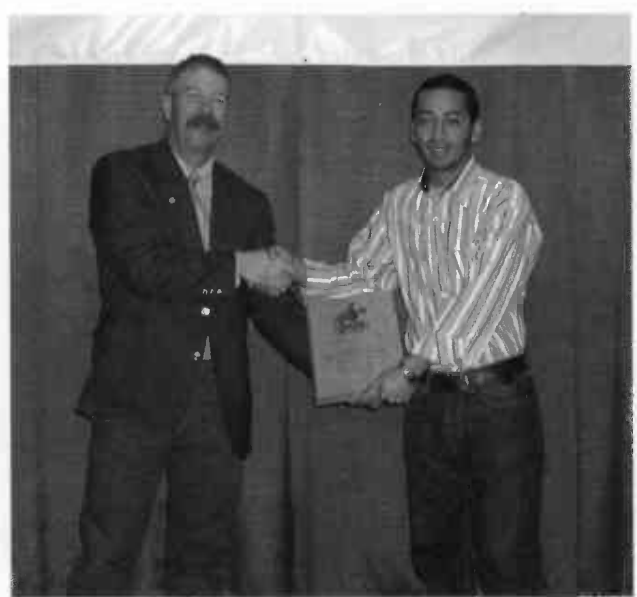

5th Place: Pascual Gallegos Ayala (Antonio Narro) and President Bob Budd.

\section{Masonic Scholarship}

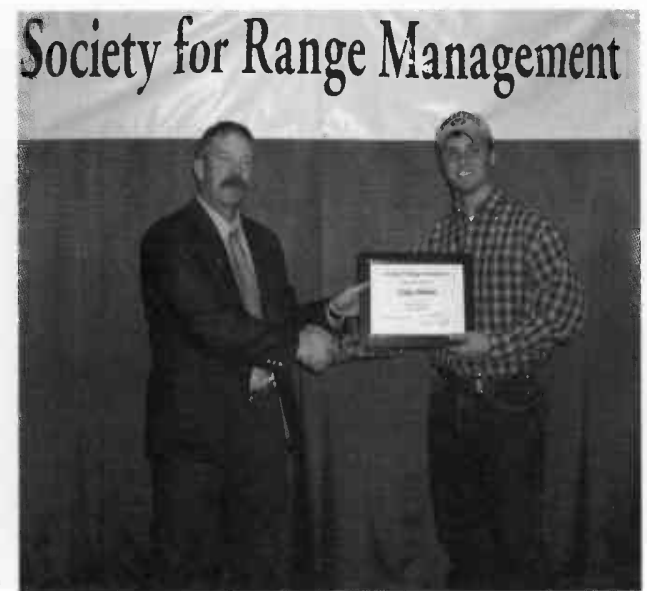

Cody Palmer (Texas Tech University) and President Bob Budd. 


\section{University Student Display Contest Winners}

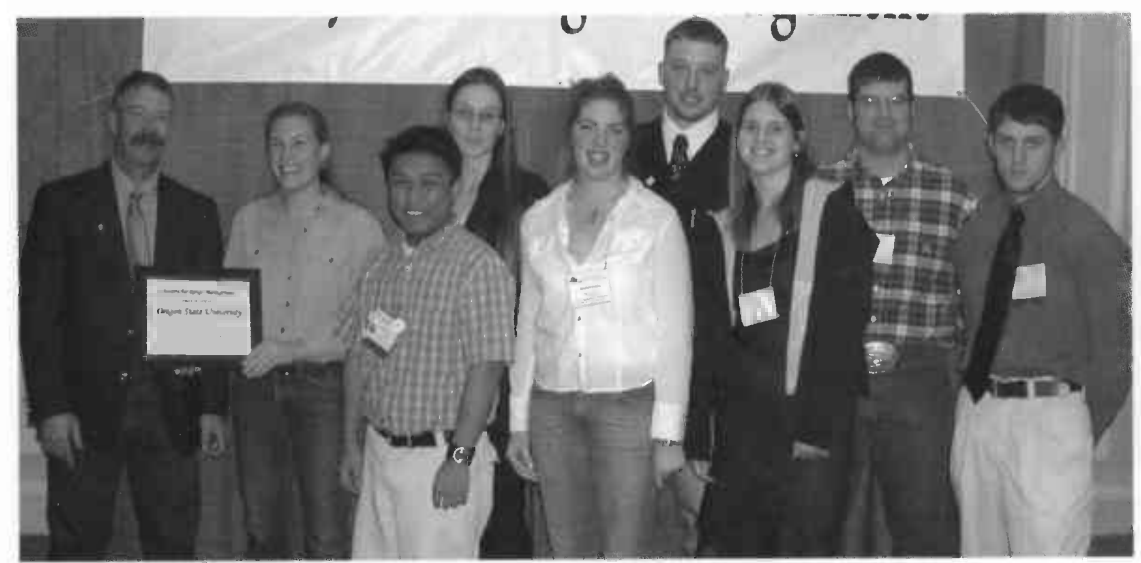

1st Place: (Oregon State University), (Alphabetically) Brooke Bays, Adrienne Cautley, Jaysen Garcia, David Gray, Hoot Paulson, Ed Rhodes, Kelly Smith, Jamie Wages and President Bob Budd.

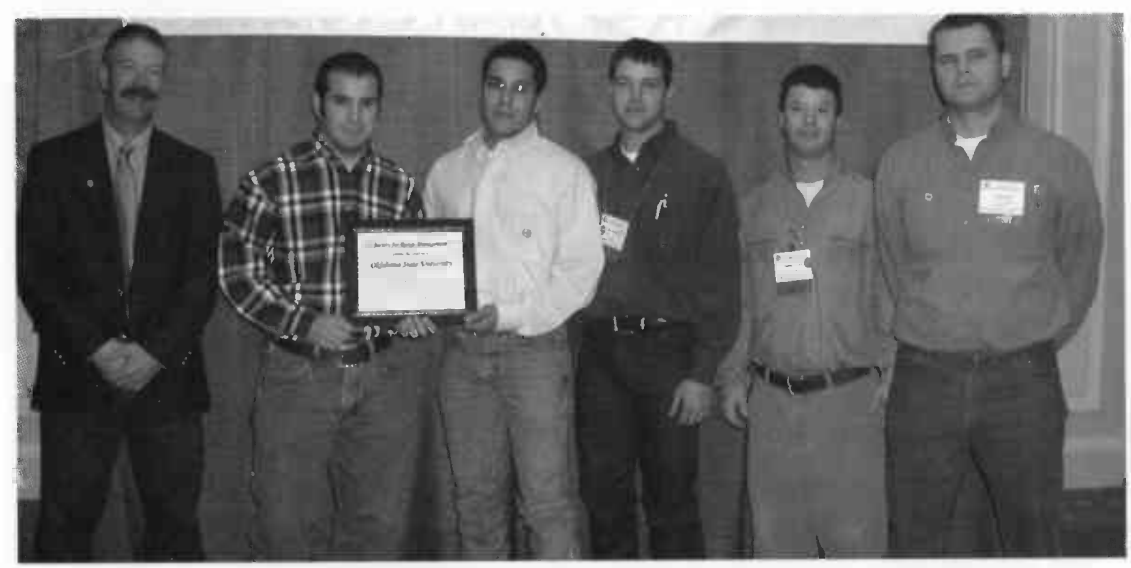

2nd Place: (Oklahoma State University), (Alphabetically) Matthew Franklin, Nick Hanigan, Aaron Perkins, Chris Rice, Austin Sewell, and President Bob Budd.

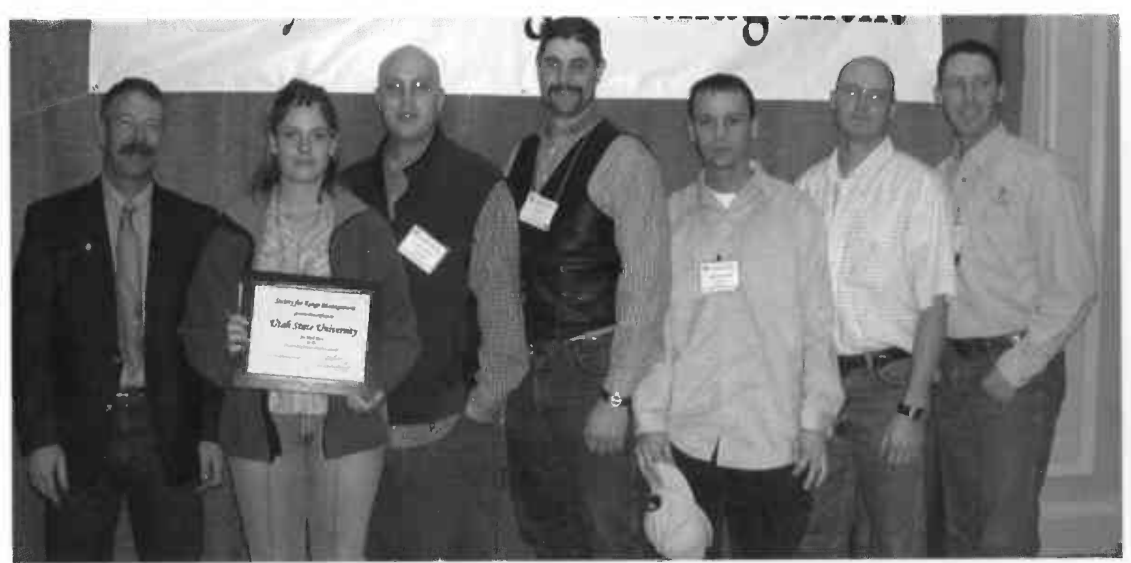

3rd Place: (Utah State University), (Alphabetically) Garry Brown, Aimee Zobell Harrison, Boyd Hatch, Morgan Mendenhall, Travis Mote, Damon Winter, and President Bob Budd.

\section{High Combined Winners}

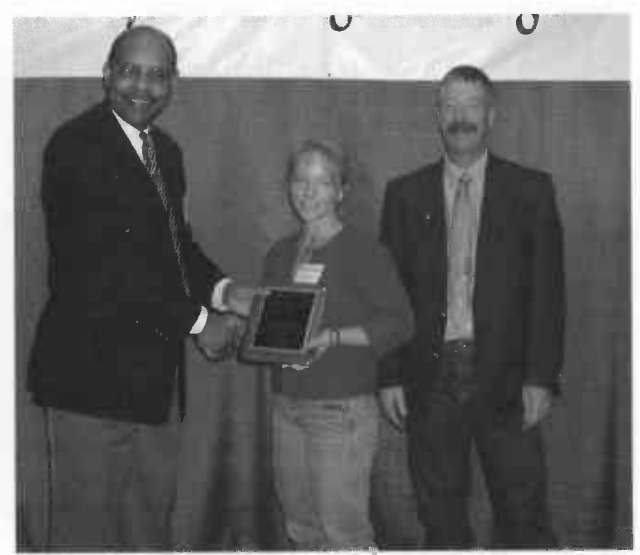

1st Place NRCE Award: Lawrence E. Clark, Jordana (Jordge) Lafantarie (Univeristy of Wyoming) and President Bob Budd.

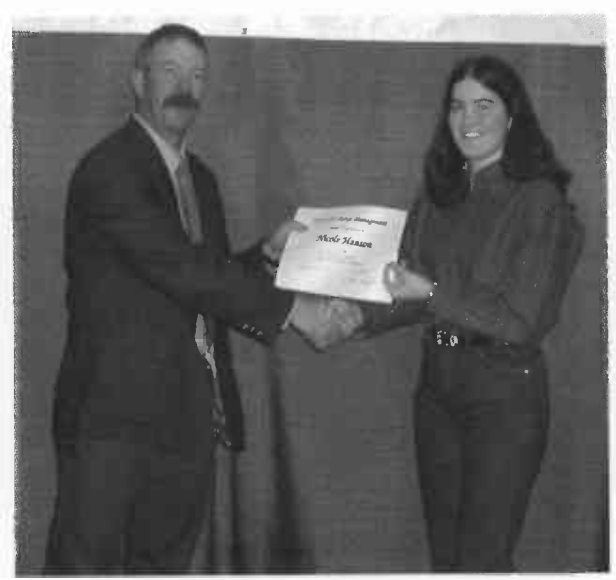

2nd Place: Nicole Hansen (South Dakota State University) and President Bob Budd.

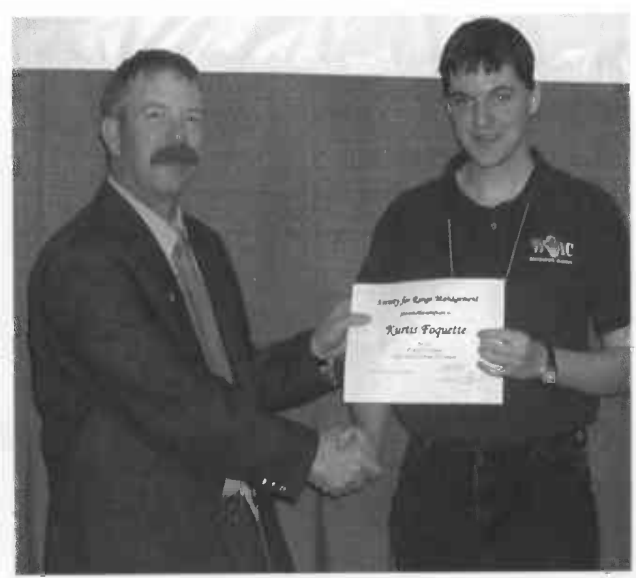

3rd Place: Kurtis Fouquetye (University of Alberta) and President Bob Budd. 


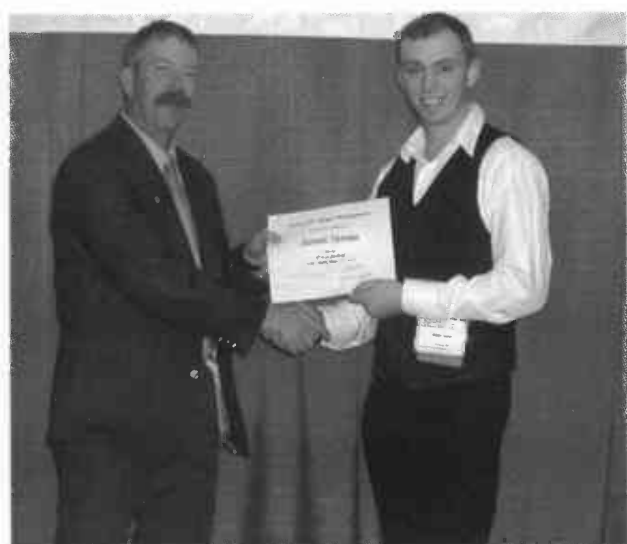

4th Place Award: Steven Tannas (University of Alberta) and President Bob Budd.

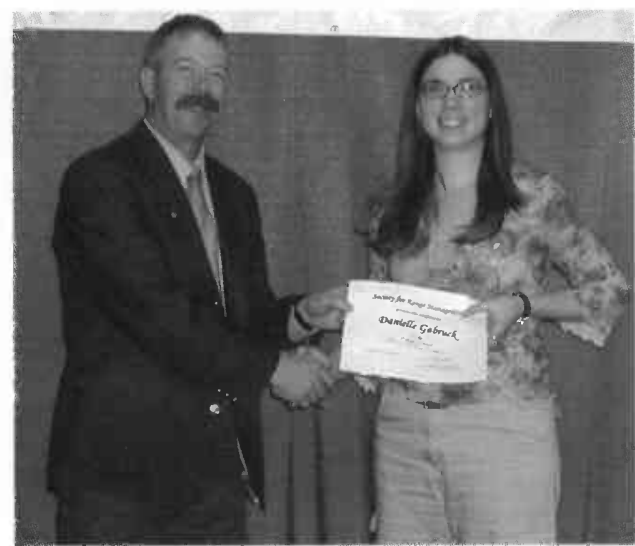

5th Place Award: Danielle Gabruck (University of Alberta) and President Bob Budd.

\section{Poster Contest Winners}

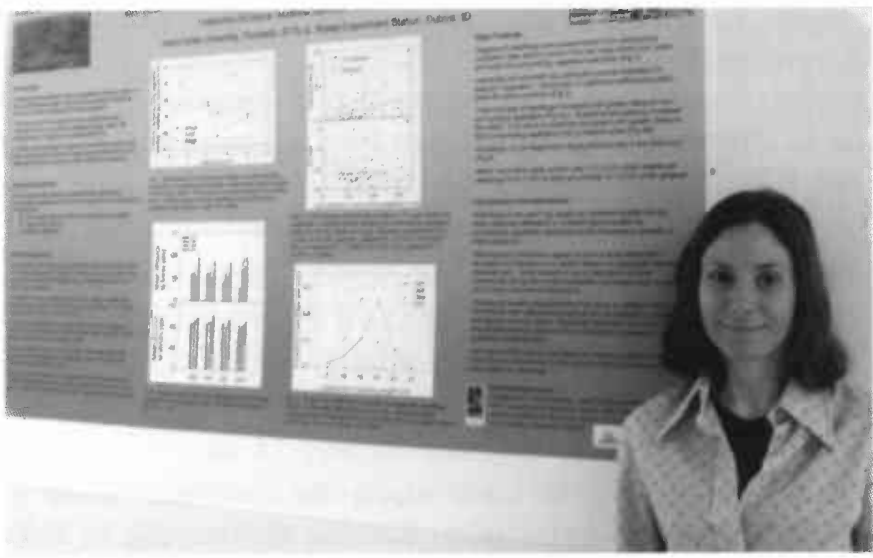

1st Place M.S. Award: Katherine DiCristina (Idaho State University)

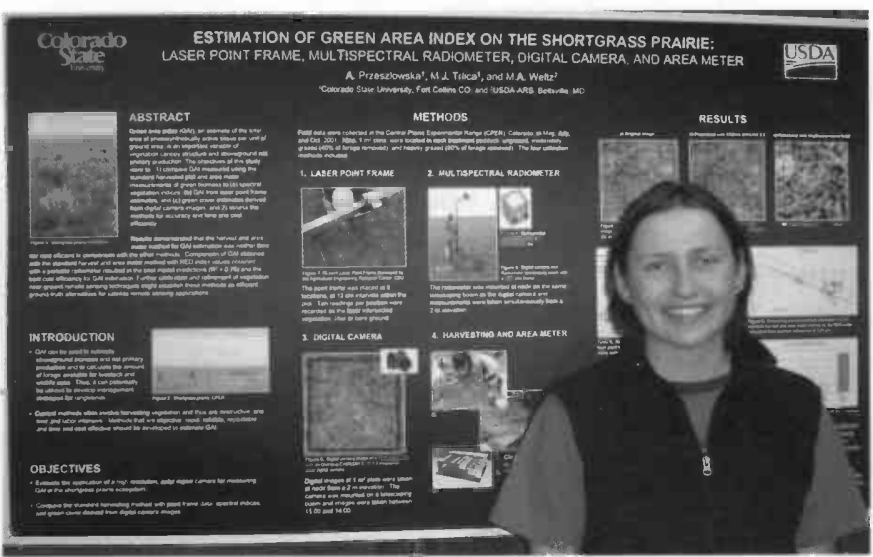

1st Place PhD. Award: Agnes Przeszlowska (Colorado State University)

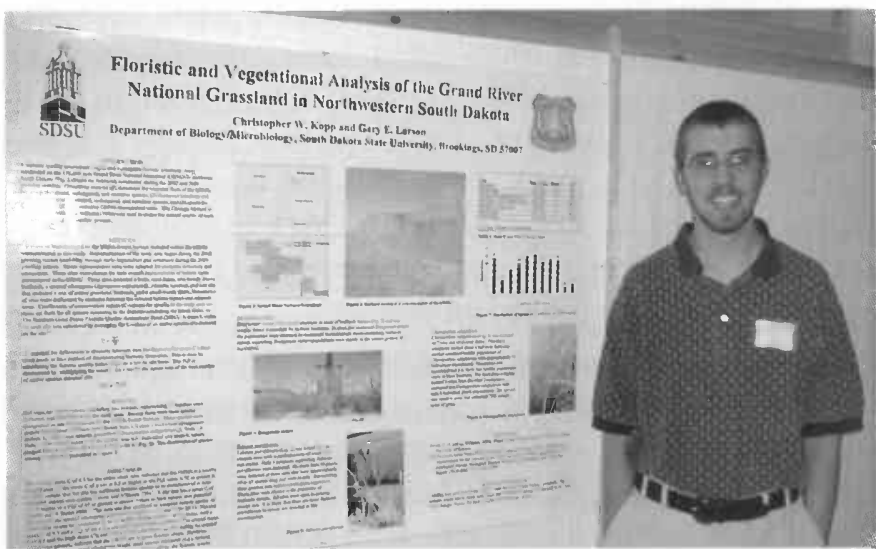

2nd Place M.S. Award: Christopher Kopp (South Dakota State University)

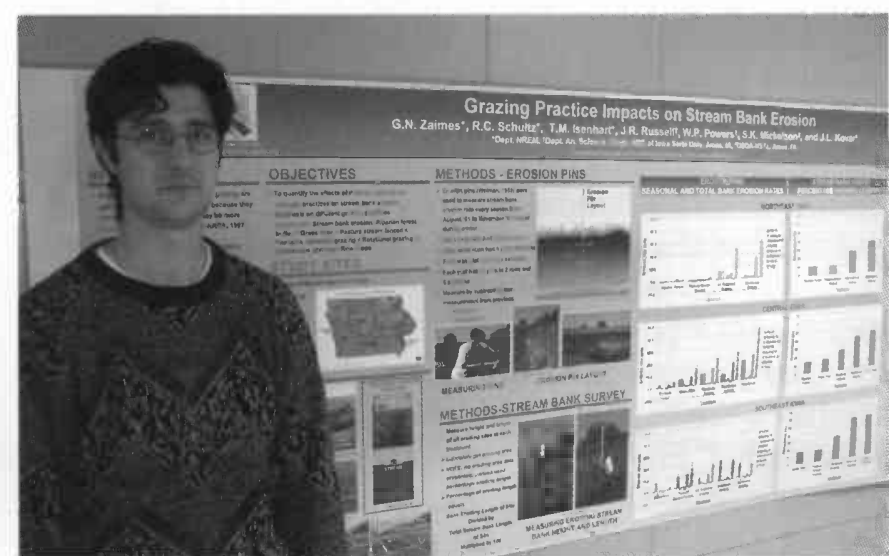

2nd Place PhD. Award: George Zaimes (Iowa State University) 